\title{
Review: Peluang Pengembangan Imbuhan Pakan Fitogenik Sebagai Pengganti Antibiotika dalam Ransum Ayam Pedaging di Indonesia
}

\author{
Cecep Hidayat ${ }^{1}$, Rahman ${ }^{2 *}$ \\ ${ }^{1}$ Balai Penelitian Ternak, PO Box 221, Bogor 16002 \\ ${ }^{2}$ Fakultas Peternakan, Universitas Halu Oleo \\ Kampus Hijau Bumi Tridharma, Jl. H.E.A. Mokodompit, Anduonohu, Kendari 93232 \\ *Email korespondensi: rahman@uho.ac.id
}

(Diterima: 19-02-2019; disetujui 18-04-2019)

\begin{abstract}
ABSTRAK
Seiring dengan telah dilarangnya penggunaan antibiotic growth promotor (AGP) dalam pakan oleh pemerintah Indonesia, maka pencarian pengganti AGP mejadi penting saat ini. Imbuhan pakan fitogenik menjadi salah satu pengganti AGP potensial. Makalah ini ditulis untuk mengungkap peluang pengembangan imbuhan pakan fitogenik sebagai pengganti AGP dalam ransum ayam pedaging di Indonesia. Metode penulisan makalah dilakukan dengan beberapa tahapan. Tahapan pertama, tahap persiapan, dilakukan dengan mengumpulkan dan membaca jurnal, makalah prosiding, buku yang diperoleh dari hasil dari pencarian pada internet. Dilanjutkan dengan memilih dan menentukan jurnal hasil penelitian, makalah ilmiah pada prosiding, buku terkait dengan topik yang sudah ditentukan. Tahapan ke dua, penyusunan outline makalah yang akan ditulis, dimana pada tahapan ini untuk menentukan skema berfikir penulis terkait dengan topik yang akan di bahas. Tahapan ke tiga, mengembangkan kerangka makalah dengan menggunakan literatur ilmiah, teori, hasil penelitian yang sudah diperoleh. Tahapan ke empat, pemeriksaan terhadap isi makalah yang sudah ditulis, baik secara substansi maupun redaksional. Berdasarkan studi pustaka yang dilakukan disimpulkan bahwa imbuhan pakan fitogenik dari berbagai jenis tanaman potensial digunakan sebagai pengganti AGP dalam pakan ayam pedaging. Kebutuhan akan daging ayam nasional yang semakin tinggi setiap tahunnya, menjadi peluang betapa besarnya pasar akan kebutuhan pengganti AGP di Indonesia. Sinergisme antara lembaga penelitian-perguruan tinggi dengan pelaku industri pakan dan imbuhan pakan menjadi penopang utama dalam pengembangan imbuhan pakan fitogenik di Indonesia.
\end{abstract}

Kata Kunci: imbuhan pakan fitogenik, ayam pedaging

\begin{abstract}
The use of antibiotic growth promoter (AGP) in feed has been banned by the Indonesian government. Therefore, the search for alternative AGP continues to be carried out. The addition of phytogenic is one of the potential alternatives because it has the same ability as AGP. This paper was written to reveal the opportunities for developing phytogenic feed additives as a substitute for antibiotics in broiler diet in Indonesia. The method of writing this paper was done in several stages. The first stage, the preparation, is done by searching and reading journals, proceedings, books obtained from the internet. The second method is the preparation of the outline of the paper to be written, to determine the author's thinking scheme related to the topic to be discussed. The third method is developing a framework of thought by using scientific literature obtained and read before. Fourth method is examination of the contents of papers that have been written, both substantially and editorially. Based on the literature study, it was concluded that the phytogenic feed additives from various types of plants should be considered as a substitute for AGP in broiler diet. The need for national chicken meat which is getting higher every year becomes an opportunity for how big the market will be for AGP's replacement in Indonesia. Synergism between university-research institutions and feed industry is the main support in developing phytogenic feed additives in Indonesia.
\end{abstract}

Keywords: pytogenic feed additive, broiler chicken 


\section{PENDAHULUAN}

Kondisi negara Indonesia sebagai negara tropis, dimana dijumpai dua musim, yaitu musim hujan dan musim kemarau. Keadaan tersebut mengakibatkan kondisi suhu dan kelembaban yang berbeda, dimana apabila dikaitkan dengan aspek budidaya peternakan ayam pedaging, memiliki dampak yang besar terhadap kinerja produksi dan kesehatan ternak. Pada musim penghujan misalnya, yang mempunyai keadaan kelembaban tinggi, akan berdampak dalam memicu tumbuh suburnya bibit penyakit. Sementara itu, pada kondisi musim kemarau, dijumpai suhu lingkungan yang tinggi, dimana hal tersebut dapat memicu stress akibat suhu panas, serta terjadinya infeksi pada saluran pernapasan. Hafni et al. (2015) mengatakan bahwa pada negara dengan iklim tropis, suhu udara berfluktuasi dari kondisi suhu rendah ke suhu tinggi, kemudian turun kembali ke suhu rendah, suhu udara akan terus berfluktuasi dalam 24 jam penuh sebagai bentuk pertukaran energi yang terjadi dilapisan atmosfer. Rataan suhu harian daerah tropis di Indonesia berkisar antara $23-28^{\circ} \mathrm{C}$ (BPS, 2017).

Bell \& Weaver (2002) melaporkan bahwa untuk menunjang kinerja produksi (pertumbuhan) optimum ayam pedaging, maka diperlukan suhu lingkungan yang nyaman untuk ayam pedaging, yaitu $18-23^{\circ} \mathrm{C}$. Kondisi peternak umumnya di Indonesia, yang masih banyak menggunakan kandang terbuka (open house), maka suhu lingkungan yang tinggi akan sangat mempengaruhi kinerja dan kesehatan ternak. Selama ini, untuk menekan dampak negatif stressor lingkungan seperti di atas, sehingga diperoleh kinerja produksi optimum serta terjaganya daya tahan tubuh ternak ayam pedaging dari serangan penyakit, dalam pakan ayam pedaging selalu diberikan suplementasi antibiotika (Lin et al., 2013).

Tantangan kemudian hadir, ketika dimulai pada bulan Januari 2018, pemerintah Indonesia melalui Kementerian Pertanian secara resmi telah melarang penggunaan antibiotik sebagai imbuhan pakan ternak. Larangan penggunaan antibiotik sebagai imbuhan pakan tertuang dalam pasal 16 Permentan No 14/2017 tentang klasifikasi obat hewan. Penggunaan antibiotik sebagai imbuhan pakan dilarang, karena antibiotik berpotensi ikut terserap pada produk hasil peternakan, dan secara tidak langsung konsumen akan memperoleh antibiotik dalam konsentrasi rendah, yang mampu meningkatkan resistensi bakteri serta residu kimia, dan mampu menimbulkan efek alergi pada manusia (Kompiang 2009). Sebelum Indonesia, pelarangan penggunaan antibiotika dalam pakan juga sudah marak secara global. Atas dasar tersebut, maka pencarian alternatif pemacu pertumbuhan yang dapat digunakan dalam ransum ayam pedaging semakin gencar dilakukan akhirakhir ini. Hal ini terlihat dari topik topik penelitian nutrisi unggas yang banyak mengambil tema terkait hal tersebut. Salah satu alternatif potensial yang banyak diteliti adalah penggunaan imbuhan pakan yang bersumber dari tanaman sebagai sumber senyawa-senyawa fitogenik, yang pada dosis tertentu dapat bermanfaat secara positif sebagai pemacu pertumbuhan dan peningkat daya tahan tubuh ayam pedaging.

Secara definisi imbuhan pakan fitogenik (sering juga disebut fitobiotik atau botanicals) biasanya didefinisikan sebagai senyawa tambahan yang merupakan hasil dari metabolit sekunder tanaman (baik mengandung senyawa bernilai nutrisi, tidak bernutrisi, ataupun anti-nutrisi) yang dimasukkan ke dalam ransum untuk meningkatkan produktivitas ternak melalui perbaikan sifat pakan, meningkatkan kesehatan saluran pencernaan dengan mengkontrol bakteri patogen, meningkatkan kinerja produksi, dan meningkatkan kualitas produk ternak (Ganguly 2013; Hashemi \& Davoodi, 2011). Murugesan et al. (2015) mengemukakan bahwa imbuhan pakan fitogenik potensial digunakan sebagai alternatif pemacu pertumbuhan untuk ternak ayam pedaging karena memiliki kemampuan yang tidak jauh berbeda dengan antibiotik dalam menjaga kesehatan saluran pencernaan ternak unggas, akan tetapi imbuhan pakan fitogenik memiliki kelebihan, yaitu tidak menimbulkan efek negatif seperti yang diakibatkan oleh antibiotika (Hashemi et al., 2008).

Beberapa laporan penelitian menunjukkan bahwa imbuhan pakan fitogenik terbukti meningkatkan kinerja pertumbuhan, memperbaiki konversi ransum, meningkatkan kualitas karkas, meningkatkan keamanan produk pangan asal ternak, mengurangi respon stres, dan meningkatkan respon imun ternak (Dhama et al., 2015; Stanacev et al., 201; Li et al., 2012; Zhang et al., 2012; Zhou et al., 2013). Disamping itu, imbuhan pakan fitogenik juga dilaporkan memiliki kemampuan sifat anti-inflamasi, antiseptik, obat penenang, 
bakterisida, fungisida, antivirus, antioksidan, peningkat palatabilitas ransum, memperbaiki fungsi usus, menstimulasi kekebalan tubuh, menstimulasi sekresi enzim pencernaan dan penyerapan zat nutrisi (Fascina et al., 2010; 2012; Steiner, 2009; McReynolds et al., 2009; Miguel et al., 2009; Cross et al., 2007; García et al., 2007). Atas dasar dampak positif yang dihasilkan oleh imbuhan pakan fitogenik maka Mathe \& Mathe (2008) memberikan analisa bahwa imbuhan pakan fitogenik dalam ransum ternak akan semakin banyak diaplikasikan ke depannya. Dalam rangka upaya mengkaji dampak penggunaan imbuhan pakan fitogenik dalam ransum ayam pedaging, terutama terkait dengan fungsinya sebagai pemacu pertumbuhan, anti bakteri alami dan immunostimulan yang berdampak positif dalam menunjang kinerja produksi ayam pedaging, maka makalah ini ditulis dengan tujuan untuk mengungkap peluang pengembangan imbuhan pakan fitogenik, sebagai pengganti antibiotika dalam ransum ayam pedaging di Indonesia, untuk dijadikan salah satu solusi atas dilarangnya penggunaan antibiotika dalam pakan, agar tetap menunjang kinerja produksi optimum ayam pedaging yang dipelihara di negara tropis seperti di Indonesia.

\section{MATERI DAN METODE}

\section{Sumber Literatur}

Literatur yang digunakan dalam makalah ini merupakan makalah yang diperoleh dari hasil pencaria menggunakan mesin pencarian karya ilmiah "Google Scholar" dengan menggunakan kata kunci "phytogenic supplementation on broiler diet". Kriteria pemilihan sumber pustaka adalah berasal dari hasil penelitian atau teori dasar yang sudah dipublikasikann dalam bentuk jurnal, makalah prosiding dan buku.

\section{Prosedur Penyusunan Makalah}

Proses penyusunan makalah dilakukan dengan beberapa tahapan. Tahapan pertama, tahap persiapan, dilakukan dengan mengumpulkan dan membaca jurnal, makalah prosiding, buku yang diperoleh dari hasil pencarian. Dilanjutkan dengan memilih dan menentukan jurnal hasil penelitian, makalah ilmiah pada prosiding, buku terkait dengan topik yang sudah ditentukan, yaitu sesuai dengan judul makalah yang akan dibuat "Peluang pengembangan imbuhan pakan fitogenik sebagai pengganti antibiotik dalam ransum ayam pedaging di Indonesia". Tahapan ke dua, penyusunan outline makalah yang akan ditulis, dimana pada tahapan ini untuk menentukan skema berfikir penulis terkait dengan topik yang akan di bahas. Tahapan ke tiga, mengembangkan kerangka pemikiran dalam penyusunan makalah dengan menggunakan informasi ilmiah, teori, hasil penelitian yang diperoleh dari pustaka yang sudah di peroleh sebelumnya untuk kemudian dibuat menjadi sebuah makalah ilmiah. Tahapan ke empat, pemeriksaan terhadap isi makalah yang sudah ditulis, baik secara substansi maupun redaksional.

\section{HASIL DAN PEMBAHASAN}

\section{Klasifikasi dan Komponen Aktif Fitogenik Sebagai Imbuhan Pakan}

Adanya larangan penggunaan antibiotik growth promotor (AGP) dalam pakan unggas secara global, telah banyak mengundang para peneliti, untuk mencari alternatif pemacu pertumbuhan lainnya, disamping menunjang keamanan pangan, juga memiliki kemampuan aktivitas sebagaimana antibiotika dalam meningkatkan kesehatan dan produktivitas ayam broiler (Barreto et al., 2008). Pemacu pertumbuhan alternatif yang paling sering digunakan dalam pakan ayam broiler adalah probiotik, prebiotik, enzim, acidifier, antioksidan dan imbuhan pakan fitogenik (Perić et al., 2009). Silva Cardoso et al. (2012) mengatakan bahwa imbuhan pakan fitogenik sebagai senyawa alami, telah diakui sebagai solusi alternatif yang sangat menjanjikan, karena memenuhi persyaratan yang diminta oleh konsumen terkait keamanan pangan, dan memecahkan masalah terkait resistensi bakteri yang terjadi pada penggunaan antibiotik.

Karaskova et al. (2015) mengklasifikasikan imbuhan pakan fitogenik diklasifikasikan menjadi beberapa kelompok, yaitu aditif sensorik (aditif pakan yang mempengaruhi sifat sensorik produk hewani), aditif teknologi (antioksidan, zat-zat yang mengurangi kontaminasi mikotoksin pada pakan dll.), aditif zootechnical (imunomodulator, immunostimulan, pemacu pertumbuhan, zat yang mampu meningkatkan kinerja atau kualitas produk hewani, dll.), dan aditif nutrisi (vitamin, mineral, enzim tanaman, dll.). Windisch et al. (2008; 2006) menjelaskan bahwa memperhatikan derivasi biologis, formulasi, deskripsi kimia, serta kemurniannya, imbuhan pakan fitogenik dapat 
dikategorikan: 1) herbal (tanaman berbunga, tanaman tidak berkayu dan tanaman tidak persisten), 2) botani (seluruh atau bagian yang diproses dari suatu tanaman, misalnya, akar, daun, kulit kayu), 3) minyak esensial (ekstrak destilasi hidro dari senyawa tanaman yang mudah menguap), dan 4) oleoresin (ekstrak menggunakan bukan pelarut air). Kandungan zat aktif dalam imbuhan pakan fitogenik sangat bervariasi tergantung pada bagian tanaman yang digunakan (misalnya biji, daun, akar atau kulit kayu), musim panen, dan asal geografis. Teknik pemrosesan (misalnya distilasi uap, ekstraksi dengan non pelarut berair dll) memodifikasi zat aktif dan senyawa yang terkait dalam produk akhir imbuhan pakan fitogenik (Windisch et al., 2008; Jacela et al., 2010).

Sementara itu, Huyghebaert et al. (2011) melaporkan bahwa komposisi kimia imbuhan pakan fitogenik bervariasi tergantung kepada bahan yang digunakan, lokasi pengambilan bahan, kondisi iklim, umur panen dan teknik penyimpanan. Beberapa faktor-faktor lain yang mempengaruhi aktivitas komponen aktif fitogenik tanaman adalah bagian tanaman yang digunakan, sifat fisik, variasi genetik tanaman, usia tanaman, dosis yang digunakan, metode ekstraksi, waktu panen, dan kompatibilitas dengan bahan lainnya (Yang et al., 2009). Beberapa peneliti melaporkan terkait kandungan bahan bio aktif pada herbal atau ekstrak tanaman yang digunakan sebagai imbuhan pakan fitogenik yaitu alkaloid, bitter, flavonoid, glikosida, getah, saponin, tanin fenolat, polifenol, terpenoid, polipeptida, timol, cineole, linalool, anethole, allicin, capsaicin, allyl isothiocyanate, minyak atsiri, dan piperine (Al-Yasiry \& Kiczorowska, 2016; Kiczorowska et al., 2015; Magdalena et al., 2012; Grashorn, 2010; Windisch et al., 2008; Wenk, 2006). Komponen aktif fitogenik dilaporkan memberikan fungsi tertentu. Minyak atsiri dilaporkan meningkatkan fungsi usus dengan merangsang sekresi enzim pencernaan, empedu dan mukosa, senyawa terpenoid dan fenolik membantu ternak dalam memerangi stress oksidatif, senyawa seperti carvacrol, terpenoid dan aldehida memberikan fungsi sebagai antimikroba (Mathlouthi et al., 2012; Burt, 2004; Platel \& Srinivasan, 2004). Mountzouris et al. (2010) mengatakan bahwa manfaat yang baik fitogenik tersebut umumnya berasal dari molekul bioaktif carvacrol, thymol, capsaicin, cineole, dll. Mekanisme kerja imbuhan pakan fitogenik dilaporkan melalui kemampuannya dalam mengendalikan bakteri patogen potensial dalam usus. Hal ini terlihat dari laporan bahwa beberapa ekstrak tanamandi laporkan memiliki sifat antimikroba, antiviral, anticoccidial, fungicidal, dan antioksidan (Applegate et al., 2010).

\section{Imbuhan Pakan Fitogenik Sebagai Antioksidan Pengendali Stres Panas pada Ayam Pedaging}

Dampak dari suhu lingkungan yang tinggi yang ada pada negara tropis seperti Indonesia, terhadap proses produksi budidaya ayam pedaging, adalah suhu lingkungan yang tinggi tersebut akan mengakibatkan terjadinya penimbunan panas dalam tubuh, sehingga ternak mengalami cekaman panas. Bird et al. (2003) mengatakan bahwa mekanisme pembuangan panas dari dalam tubuh ternak unggas dilakukan melalui dua cara, yaitu secara sensible heat loss dan insensible heat loss. Sensible heat loss adalah hilangnya panas tubuh melalui proses radiasi, konduksi dan konveksi, sedangkan secara insensible heat loss adalah hilangnya panas tubuh melalui proses panting. Pada suhu pemeliharaan $23^{\circ} \mathrm{C} 75 \%$ panas tubuh dibuang secara sensible, selebihnya (25\%) dikeluarkan secara insensible, sebaliknya bila suhu lingkungan meningkat sampai $35^{\circ} \mathrm{C}$ sebanyak $75 \%$ panas tubuh dibuang melalui proses insensible dan sisanya sebanyak $25 \%$ dibuang secara sensible (Tamzil et al., 2014).

Beberapa peneliti melaporkan terkait dampak cekaman panas pada ayam pedaging, dari mulai mengakibatkan menurunnya konsumsi ransum, hingga menurunnya tingkat pertumbuhan, meningkatkan suhu tubuh, terjadinya variasi $\mathrm{pH}$ darah akibat ketidak seimbangan elektrolit, menurunnya kekebalan tubuh, perubahan fungsi reproduksi, dilaporkan lebih sedikitnya energi yang tersedia untuk sel, ketidakseimbangan dalam kecernaaan dan metabolisme beberapa zat nutrisi, terganggunya mikroflora usus dan mukosa usus (Lara \& Rostagno, 2013; Renaudeau et al., 2012; Syafwan et al., 2011). Suhu lingkungan tinggi tersebut juga dilaporkan menyebabkan terjadinya cekaman oksidatif dalam tubuh ayam, yang menimbulkan munculnya radikal bebas yang berlebihan (Rahman 2003). Mempertegas hasil tersebut, Mujahid et al. (2005) mengatakan bahwa kenaikan suhu lingkungan $5^{\circ} \mathrm{C}$ yang melebihi 
kisaran zona nyaman ayam broiler dapat menyebabkan stres oksidatif (kondisi aktvitas radikal bebas melebihi antioksidan) pada ayam broiler. Lin et al. (2006) menyatakan bahwa stres oksidatif dianggap sebagai salah satu faktor utama penyebab menurunnya kinerja produksi pada industri ternak unggas dan menjadi faktor utama penyebab beberapa penyakit serius (Kris-Etherton et al., 2004).

Radikal bebas merupakan suatu molekul, atom, atau grup beberapa atom yang memiliki elektron yang tidak berpasangan akan menarik elektron dari senyawa lain di sekitarnya, misalnya dari protein, lipid, karbohidrat, dan DNA (deoxyribo nucleat acid), yaitu senyawa yang terdapat dalam inti sel, sehingga sel-sel ini akan mengalami kerusakan yang akhirnya akan menyebabkan berbagai macam penyakit (Chludil et $a l .$, 2008). Dalam konsentrasi yang tinggi, radikal bebas akan menyebabkan stres oksidatif, suatu proses penghancuran yang dapat merusak seluruh sel tubuh (Pham-Huy et al., 2008). Radikal bebas secara alami sudah terbentuk di dalam tubuh melalui berbagai proses kimiawi yang kompleks. Kondisi ini merupakan hasil sampingan dari proses oksidasi atau pembakaran di dalam sel. Proses kerusakan tubuh ini terjadi bila tidak diimbangi dengan kadar antioksidan tubuh yang baik. Sehingga, untuk menekan terjadinya stres akibat cekaman panas dapat dilakukan suplementasi antioksidan dalam pakan/air minum ayam pedaging. Antioksidan merupakan inhibitor yang bekerja menghambat oksidasi dengan cara bereaksi dengan radikal bebas reaktif membentuk radikal bebas tak reaktif yang relatif stabil atau senyawa yang melindungi sel dari efek berbahaya radikal bebas oksigen reaktif (Laguerre et al., 2007) atau secara sederhana antioksidan berfungsi merubah senyawa berbahaya dalam tubuh menjadi tidak berbahaya.

Mekanisme bagaimana suhu lingkungan yang tinggi (cekaman panas) menyebabkan stress oksidatif pada ternak ayam pedaging adalah dikarenakan cekaman panas dapat menyebabkan gangguan homeostasis sel dimana gangguan homeostasis sel tersebut dimediasi oleh reactive oxygen species (ROS) yang diproduksi oleh sel sebagai respon terhadap stressor (cekaman panas) (Afanas'ev et al., 2010; Rocha et al., 2010). Chirag et al. (2013) menjelaskan bahwa yang paling umum dari bentuk ROS adalah anion superoksida
$(\mathrm{O} 2)$, hidrogen peroksida $(\mathrm{H} 2 \mathrm{O} 2)$, radikal peroxyl (ROO) dan radikal hidroksil reaktif $(\mathrm{OH})$. Izyumov et al. (2010) melaporkan bahwa cekaman panas selain memicu produksi ROS (Reactive Oxygen Spesies), pada saat yang sama juga memicu produksi antioksidant enzymatic seperti catalase (CAT), hydroperosidase (HPx), superoksida dismutase (SOD). Apabila produksi ROS melebihi kapasitas antioksidan yang ada, maka akan menyebabkan terjadinya stress oxidative (Turan et al., 2010; Botham et al., 2009). Meskipun demikian, masih tetap ada ROS yang terbentuk meskipun dalam jumlah yang kecil, oleh karena itu perlu antioksidan tambahan lain seperti vitamin $\mathrm{E}$, vitamin $\mathrm{C}$, flavonoid, asam urat, dll, mengingat rantai reaksi ROS hanya dapat dihentikan dengan reaksi dua ROS secara bersama sehingga dua electron yang tidak berpasangan menjadi berpasangan.

Salah satu upaya yang banyak dilakukan dalam mengatasi cekaman panas pada ayam pedaging adalah melalui pemberian imbuhan pakan fitogenik dari beberapa tanaman. Santos-Cervantes et al. (2007) menyatakan bahwa tanaman adalah sumber utama metabolit bioaktif dengan aktivitas antimutagenik dan anti karsinogenik (misalnya fenol, quinon, glukosinolat, allyl sulfida, terpenoid, dan alkaloid), dan beberapa penelitian menunjukkan bahwa senyawa tersebut memiliki kapasitas sebagai antioksidan. Zhang et al. (2009) mengatakan bahwa penggunaan antioksidan alami dari ekstrak tanaman, terus mengalami peningkatan seiring dengan pembatasan penggunaan komponen sintesis secara global. Sahin et al. (2013) melaporkan bahwa senyawa fitogenik dalam tanaman mampu menekan dampak negatif yang diakibatkan oleh cekaman panas pada ternak ayam pedaging. Sementara itu, Chrpová et al. (2010) mengemukakan bahwa komponen aktif tanaman, yaitu polifenol, memiliki kapasitas sebagai antioksidan yang kuat. Tanin terhidrolisasi sebagai bagian dari polifenol juga dilaporkan merupakan sumber antioksidan yang kuat (Madrigal-Carballo et al., 2009). Beberapa laporan terkait penggunaan imbuhan pakan fitogenik sebagai antioksidan dalam ransum ayam pedaging sudah banyak dilaporkan, diantaranya adalah tanaman antanan/pegagan (Centella asiatica (L.) Urban), merupakan salah satu tanaman yang memiliki zat aktif asam asiatik, asiatikosida, dan asam madekasik yang terbukti dapat mengatasi cekaman 
pada tikus (Kumar \& Gupta, 2003). Kusnadi (2008) melaporkan bahwa penggunaan antanan sebanyak 5 dan $10 \%$ dalam ransum dapat menekan cekaman oksidatif ayam broiler yang tercermin dari turunnya kandungan Malondialdehyde (MDA) hati, lemak karkas dan kolesterol plasma pada ayam broiler yang mengalami cekaman. Tanaman kunyit juga dilaporkan memiliki fungsi sebagai antioksidan pada ayam pedaging. Sejati (2002) mengatakan bahwa kunyit mengandung 3\% kurkumin dan $3 \%$ minyak atsiri. Ariyanto et al. (2013) melaporkan bagaimana mekanisme kerja kunyit pada tubuh ayam pedaging sebagai berikut, yaitu melalui peningkatan kerja organ pencernaan, merangsang keluarnya getah pankreas yang mengandung enzim amilase, lipase, dan protease. Kurkumin, senyawa yang terkandung pada kunyit, berfungsi sebagai antioksidan yang bekerja pada jaringan, terutama jaringan hati, dengan mengurangi oksidan pada tubuh (Sidiq \& Wardani, 2014). Pratikno (2010) merekomendasikan penambahan kunyit sebanyak $400 \mathrm{mg} / \mathrm{kg}$ dalam ransum ayam pedaging.

Zhang et al. (2009) melaporkan bahwa tanaman jahe meningkatkan aktivitas enzim antioksidan; glutathione peroxidase (GSHPx), superoxide dismutase (SOD), dan menurunkan tingkat Malondialdehyde (MDA) ayam broiler yang diberi pakan dengan suplementasi jahe pada dosis $5 \mathrm{~g} / \mathrm{kg}$. Sahin et al. (2008) melaporkan bahwa lycopene dari tomat dapat digunakan sebagai sumber antioksidan pada pakan ayam pedaging dan memberikan dampak positif pada peningkatan kinerja pertumbuhan serta menekan peroksidasi lemak. Lycopene adalah pigmen karotenoid yang dominan secara umum ditemukan dalam buah dan sayuran, terutama tanaman tomat. Sahin et al. (2006a; 2006b) melaporkan bahwa suplementasi lycopene memberikan dampak positif terhadap status antioksidan dan kinerja pertumbuhan ternak puyuh yang diberi cekaman panas. Sementara itu, Selim et al. (2013) mengemukakan hasil penelitian pada ayam broiler yang diberi cekaman panas, dimana dilaporkan bahwa suplementasi 5\% lycopene dalam ransum dapat meningkatkan kinerja pertumbuhan, bahkan pada level yang lebih rendah (1\%), mampu meningkatkan kapasitas antioksidan total dan menurunkan tingkat MDA. Soares et al. (2008) melaporkan bahwa kulit buah apel kaya senyawa polifenol yang mengandung senyawa antioksidan.
Sementara itu, Heidarisafar et al. (2016) menunjukkan bahwa penggunaan limbah kulit apel (maximum $50 \mathrm{~g} / \mathrm{kg}$ ) pada pakan grower ayam pedaging memberikan dampak positif terhadap kinerja pertumbuhan, dan memiliki potensi sebagai antioksidan karena memiliki kemampuan dalam menurunkan MDA serum.

Sumber tanaman yang potensial lainnya sebagai sumber antioksidan adalah daun jambu biji (Lee et al., 2012; Rivai et al., 2010). Bintarti (2014) melaporkan bahwa ekstrak etanol dan fraksi air daun jambu biji mempunyai aktifitas antioksidan berkategori kuat, pada fraksi n-heksan dan etil asetat mempunyai antioksidan berkategori sedang. Maulana et al. (2016) melaporkan bahwa senyawa golongan flavonoid yang teridentifikasi dalam ekstrak daun jambu biji putih (Psidium Guajava Linn) merupakan golongan senyawa flavon yang memiliki gugus fungsi yaitu $\mathrm{CH}$ alifatik, $\mathrm{CH}$ aromatik, $\mathrm{C}=\mathrm{C}$ aromatik, $\mathrm{C}=\mathrm{O}, \mathrm{OH}$ dan $\mathrm{C}-\mathrm{O}$, dan kemungkinan gugus $\mathrm{OH}$ di nomor atom $\mathrm{C}-2$ ', $\mathrm{C}-3$ dan terdapat gugus ortodihidroksi di nomor atom C-4',C-5'; C-5',C-6, serta pada atom $\mathrm{C}-7$ terdapat gugus O-glikosida, dimana hasil uji aktivitas antioksidan terhadap DPPH dari ekstrak n-butanol daun jambu biji putih (Psidium Guajava Linn) dapat digunakan sebagai antioksidan karena memiliki nilai IC50 sebesar 37,1402 ppm. Qian et al. (2004) melaporkan bahwa ekstrak etanol dan ekstrak air daun jambu biji ( $P$. guajava) mengandung kandungan total fenol yang tinggi $(575,3 \pm 5,5$ dan 511,6 $\pm 6,2 \mathrm{mg}$ ekivalen asam galat /g). Aktivitas antioksidan dari berbagai pelarut (air, etanol, metanol, dan berbagai konsentrasi hidroethanol) untuk daun jambu biji (P. Guajava) telah menunjukkan adanya hubungan yang kuat antara kemampuan antioksidan ekstrak daun jambu biji dengan senyawa fenolik saat dibandingkan dengan konten flavonoid (Seo et al., 2014).

\section{Imbuhan Pakan Fitogenik Sebagai Antimikroba Alami}

Peternakan ayam pedaging rentan terhadap serangan penyakit yang disebabkan oleh virus, bakteri, parasit, jamur, lingkungan dan kekurangan salah satu unsur nutrisi. Untuk meningkatkan daya tahan tubuh ayam pedaging terhadap serangan penyakit, selama ini digunakan antibiotik pada pakan. Soares et al. (2012) mengatakan bahwa antibiotika adalah zat yang diproduksi oleh 
berbagai spesies mikroorganisme (bakteri, jamur, actinomycetes) yang mampu menekan pertumbuhan dan membunuh mikroorganisme lain yang merugikan. Penggunaan antibiotika dalam pakan juga dimaksudkan untuk memacu pertumbuhan ternak. Penggunaan antibiotik sebagai pemacu pertumbuhan mulai dilakukan sejak tahun 1950-an (Schmieder \& Edwards, 2012). Beberapa jenis antibiotik yang digunakan sebagai pemacu pertumbuhan adalah penisilin, makrolida, sulfonamid, tetrasiklin, pleuromutilin, polipeptida, streptogramin, carbadox, bambermycin (Becker, 2010). Tetracycline, chlortetracycline dan oksitetrasiklin menjadi jenis antibiotika paling banyak sering digunakan pada unggas (Ambrožič Avguštin, 2012).

Milanov et al. (2016) menjelaskan mekanisme yang tepat dari manfaat antibiotik sebagai pemacu pertumbuhan ternak adalah sebagai berikut, yaitu di sampaikan bahwa pada hewan monogastrik, pada saluran pencernaannya, terdapat 400-500 spesies bakteri yang berbeda, terutama obligat anaerob seperti Bacteroides, Bifidobacterium dan Clostridium, tetapi juga beberapa aerob dan anaerob fakultatif (lactobacilli, streptococci, Escherichia coli) (Richards et al., 2005). Jumlah bakteri meningkat sepanjang bagian saluran pencernaan, pada bagian proksimal terdapat 103-105 CFU/gram digesta dan dalam isi kolon sebanyak 1010-1012 CFU/g (Richards et al., 2005; Dibner \& Richards, 2005). Beberapa peneliti melaporkan bahwa mikrobiota pada saluran pencernaan melakukan fungsi penting dalam proses metabolisme, sintesis asam lemak rantai pendek dan vitamin esensial (B dan K), dan mempengaruhi kesehatan dan kinerja dari hewan monogastrik inang (Richards et al., 2005; Dibner \& Richards, 2005). Proporsi mikrobia saluran pencernaan terhadap jumlah sel-sel usus ternak inang rata-rata $10: 1$, itulah sebabnya mengapa mikrobiota saluran pencernaan bersaing dengan sel inang dalam pemanfaatan zat gizi pakan. Dengan demikian, pemberian antibiotik untuk menekan jumlah mikrobiota saluran pencernaan akan menghasilkan lebih banyak komponen pakan yang tersedia untuk ternak inang. Selain hal tersebut, Modi et al. (2011) melaporkan bahwa beberapa produk metabolisme mikrobiota pada saluran pencernaan juga dilaporkan merupakan senyawa beracun, seperti amonia, amina, fenol dan indola, yang semuanya akan menghambat pertumbuhan ternak. Bahkan, keberadaan mikrobiota menyebabkan penebalan lamina propria di dinding usus dan villi, sehingga berdampak pada menurunnya kecernaan nutrisi zat gizi pakan.

Maraknya pelarangan penggunaan antibiotika dalam pakan secara global, telah banyak merangsang para peneliti untuk mencari alternatif antibiotika alami. De Lange et al. (2010) mengatakan bahwa terdapat peningkatan jumlah penelitian yang signifikan yang difokuskan pada pencarian alternatif antibiotik sebagai antimikroba dan pemacu pertumbuhan yang memiliki efek serupa dengan antibiotika namun tidak menyebabkan resistensi bakteri dan menimbulkan dampak negatif berupa efek samping yang merugikan pada ternak. Diantaranya adalah dengan menggunakan asam organik (De Lange et al., 2010), enzim (Bedford \& Cowieson, 2012), probiotik (Musa et al., 2009), prebiotik (Gibson et al., 2004), peptida antimikroba (Choi et al., 2013) dan senyawa fitogenik (Gong et al., 2014; Randrianarivelo et al., 2010; Windisch et al., 2008), yang telah secara luas diakui sebagai alternatif potensial untuk antibiotik dalam pakan. Athanasiadou et al. (2007) melaporkan bahwa imbuhan pakan fitogenik potensial untuk menjadi alternatif pengganti antibiotika karena mampu menekan bakteri patogen dalam usus.

Aktivitas antimikroba imbuhan pakan fitogenik sangat ditentukan oleh karakteristik fisiko-kimia senyawa tanaman (Muthusamy \& Sankar, 2015). Hasil studi menunjukkan bahwa aktivitas antibiotika dalam mengkontrol bakteri patogen melalui penyerangan mesin biosintesis dari dinding sel bakteri yang menjadi target paling banyak yang diserang oleh senyawa antimikroba (Faleiro, 2011; Yap et al., 2014). Minyak esensial sebagai komponen fitogenik dari ekstrak tanaman dilaporkan juga dapat merusak kedua dinding sel bakteri (termasuk membran) dan sitoplasma. Sehingga dengan sifatnya tersebut minyak essensial dari ekstrak tanaman dianggap potensial sebagai alternatif antibiotik dalam sistem produksi ternak (Delaquis et al., 2002). Beberapa peneliti juga telah melaporkan bahwa minyak essensial yang terkandung dalam imbuhan pakan fitogenik mengandung sebagian besar zat bioaktif dari 
tanaman yang meliputi carvacrol, eugenol, thymol, capsaicin, cineole dan sebagainya yang banyak dilaporkan memiliki sifat sebagai antibakteri, antijamur, antiviral dan anti coccidial (Farag et al., 2016; Patil \& Patil, 2016; Dragan et al., 2014; Gopi et al., 2014; Oyuntsetseg et al., 2014; Giannenas \& Kyriajakis, 2009; Windisch et al., 2008). Minyak esensial yang mengandung persentase komponen fenolik yang tinggi (misalnya carvacrol dan thymol) menunjukkan memiliki kapasitas penghambatan bakteri yang lebih tinggi dibandingkan dengan minyak essensial yang mengandung, sebagai contoh monoterpenis alkohol linalool alkohol (Penalver et al., 2005).

Ultee et al. (2002) menjelaskan bahwa minyak esensial mampu meningkatkan permeabilitas membran sel bakteri yang mengakibatkan kebocoran isi sel dan akhirnya membunuh sel. Kebocoran biasanya terjadi melalui degradasi dinding sel, kerusakan membran sitoplasma, koagulasi sitoplasma dan penghancuran protein membran. Kemampuan menekan bakteri dari minyak essensial terhadap bakteri gram positif dan negatif berbeda, seperti dijelaskan oleh Trombetta et al. (2005), yang menyatakan bahwa sekitar 90-95\% dinding sel bakteri Gram-positif (G+), terdiri dari peptidoglikan yang memungkinkan molekul hidrofobik, dengan mudah menembus sel, dan menyerang pada dinding sel, atau sitoplasma. Saat memasuki sel, senyawa fenolik dapat mengganggu enzim yang terlibat dalam produksi energi pada konsentrasi yang lebih rendah, dan mendenaturasi protein pada konsentrasi yang lebih tinggi. Di sisi lain, lapisan peptidoglikan pada bakteri Gramnegatif $\left(\mathrm{G}^{-}\right)$tebalnya hanya $2-3 \mathrm{~mm}$, dan hanya membentuk $20 \%$ dari berat kering sel. Terdapat suatu membran yang terletak di luar lapisan peptidoglikan, dimana terdiri dari lapisan ganda fosfolipid, yang dihubungkan erat oleh lipoprotein Braun ke membran dalam. Umumnya, bakteri bakteri gram negatif, lebih tahan terhadap minyak essensial daripada bakteri bakteri gram positif, hal ini dikarenakan terdapatnya membran luar tebal dalam bakteri gram negatif, yang membuatnya memiliki lapisan tambahan perlindungan. Lambert et al. (2001) menerangkan bahwa aktivitas minyak essensial pada sel mikroba bervariasi tergantung lokasi gugus hidroksil atau alkil fungsional mereka. Misalnya, timol dan carvacrol, dua terpenoid umum, memiliki efek antimikroba, yang serupa tetapi bertindak berbeda terhadap bakteri $G$ + atau $\mathrm{G}^{-}$, tergantung pada lokasi dari satu atau lebih grup fungsional dalam dua molekul tersebut. Grup hidroksil dari terpenoid fenolik, dan terdapatnya elektron terdelokalisasi, merupakan elemen penting pada seberapa besar kemampuan aktiivitas antimikroba minyak essensial (Ultee et al., 2002; Lambert et al., 2001).

Beberapa peneliti melaporkan terkait pengujian aktivitas antimikroba dari minyak essensial secara in vitro yang mampu menghambat bakteri E. coli, Salmonella sp, Clostridium perfringens (C. Perfringens) (Jugl-Chizzola et al. 2005; Penalver et al. 2005; Ben Arfa et al. 2006). Beberapa penelitian dengan ternak unggas menunjukkan secara jelas bahwa terjadi pengurangan $C$. Perfringens di jejunum dan sekum ayam pedaging yang diberi campuran komponen minyak essensial (Mitschet et al., 2004). Sebuah penelitian untuk menguji efisiensi carvacrol, thymol, trans-cinnamaldehyde dan tetrasodium pyrophosphate pada radiosensitisasi E. coli dan Salmonella typhi pada dada ayam, menunjukkan bahwa senyawa aktif ini membantu mengurangi secara signifikan jumlah E. coli dan S. typhi (Lacroix et al., 2004). Sehingga, penambahan minyak essensial ke dalam pakan memberikan dua manfaat sekaligus, yaitu mengurangi mikroba dalam saluran pencernaan juga meningkatkan kehigienisan karkas yang dihasilkan dari mikroba (Aksit et al., 2006).

Laporan penelitian terkait penggunaan ekstrak tanaman sebagai penghambat pertumbuhan bakteri Escherichia coli dan C. Perfringens sudah banyak dilaporkan. Dahiya et al. (2006) melaporkan bahwa minyak essensial dari rhizoma kunyit (Curcuma longa) dan Eugenol dari cengkeh (Syzygium aromaticum) mampu menekan pertumbuhan $C$. Perfringens. Bakteri $C$. Perfringens juga dilaporkan dapat dihambat oleh Astaxanthin dari alga merah (Haematococcus Pluvalis) (Waldenstedt et al., 2003), Lupulone dari tanaman hops (Humulus lupulus) (Siragusa et al., 2008). Becker \& Galletti (2008) melaporkan bahwa beberapa tanaman mampu menekan pertumbuhan bakteri E. coli, yaitu Artichoke (Cynara cardunculus var scolymus); biji wijen 
(Sesamum indicum); ekstrak Palm kernel (Aracaceae elais); tomat (Solanum lycopersicum). Bakteri E. coli juga dilaporkan dapat ditekan pertumbuhannya oleh ekstrak jambu biji (Psidium Guajava) (Geidam et al., 2005).

Daun jambu biji (Psidium guajava L) dilaporkan oleh Biswas (2013) sebagai bagian dari tanaman yang mengandung senyawa antimikroba, yaitu tanin, minyak essensial (eugenol), minyak lemak, resin, triterpenoid, flavonoid, asam malat. Senyawa antimikroba pada daun jambu biji memiliki kemampuan dalam menekan bakteri gram positif dan negatif (Biswas, 2013). Kaneria \& Chanda (2011) mengatakan juga bahwa daun jambu biji mengandung fitokimia dengan spektrum yang luas termasuk mineral, enzim, protein, alcohol sesquiterpenoid, asam triterpenoid, alkaloid, glikosida, steroid, flavanoids, tanin, saponin (Haida et al., 2011). Ryu et al. (2012) juga melaporkan bahwa jambu biji sangat kaya akan lutein, zeaxanthine, dan lycopene. Selain itu, tiga flavonoid (quercetin, avicularin, dan guaijaverin) dilaporkan terkandung pada daun jambu biji (Psidium guajava) (Huang et al., 2011). Flavonoid yang diekstrak dari daun jambu biji termasuk morin-3-O-lyxoside, morin-3-O-arabinoside, quercetin, dan quercetin-3-O-arabinoside dilaporkan memiliki aktivitas antibakteri yang kuat (Arima \& Danno 2002). Secara kuantitatif, daun jambu biji (Psidium guajava) mengandung sejumlah besar polifenolik terlarut $(\mathrm{mg} / \mathrm{g})$ asam galat (348), catechin (102), epicatechin (60), rutin (100), quercetin (102), dan rutin (100) (Chen et al., 2009).

Gallocatechin yang diisolasi dari ekstrak metanol daun jambu biji menunjukkan aktivitas antimutagenik terhadap Escherichia coli (Manosroi et al., 2006). Limsong et al. (2004) melaporkan bahwa Senyawa flavonoid aktif - quercetin-3Oalpha- 1-arabinopyranoside (guaijaverin) - yang diekstraksi dari daun jambu biji mampu menghambat pertumbuhan Streptococcus mutans. Lin et al. (2002) melaporkan bahwa ekstrak daun jambu biji ( $P$. Guajava) menunjukkan aktivitas penghambatan terhadap tiga spesies Salmonella; Shigella flexneri, Shigella virchow, dan Shigella dysenteriae, dan dua varietas $E$. coli enteropatik. Hasil penelitian lainnya, menunjukkan bahwa jambu biji menunjukkan aktivitas antibakteri yang signifikan terhadap bakteri penyebab diare yang disebabkan oleh bakteri seperti Staphylococcus spp., Shigella spp., Salmonella spp., Bacillus spp., E. coli, Clostridium spp., dan bakteri pembusuk makanan seperti Pseudomonas spp. (Hidetoshi \& Danrio, 2002; Abdeirahirn et al., 2002). Ekstrak air dari jambu biji (Psidium Guajava) dilaporkan lebih kuat dalam menghambat pertumbuhan bakteri patogen Proteus mirabilis, Streptococcus pyogenes, Escherichia coli, Staphylococcus aureus dan Pseudomonas aeruginosa daripada ekstrak organik (Abubakar, 2009).

\section{Imbuhan Pakan Fitogenik Sebagai Immunostimulan}

Ternak ayam pedaging, seperti hewan lain, memiliki mekanisme pertahanan tubuh melalui sistem pertahanan berupa respon imun nonspesifik dan spesifik untuk merespon adanya potensi infeksi ancaman dari bakteri, virus, parasit, dan bahan antigenik lainnya. Dua jenis respon imun adalah yang bersifat bawaan (innate) (tidak spesifik), serta yang diperoleh dari luar (acquaired) (spesifik). Kedua tipe respons ini biasanya terkoordinasi; serangan patogen awalnya diproses oleh sistem imun bawaan (innate), dan, jika perlu, acquaired respons kemudian diaktifkan (Erf, 2004). Tanaman obat dilaporkan dapat mempengaruhi mekanisme pertahanan atau sistem imunitas tubuh yang meliputi sistem imunitas spesifik dan nonspesifik (Spelman et al., 2006). Untuk meningkatkan daya tahan tubuh ternak dari serangan penyakit, tanaman sebagai sumber imbuhan pakan fitogenik banyak digunakan sebagai immunostimulan dalam pakan. Imunostimulan merupakan zat yang mendorong dan menopang sistem kekebalan tubuh dalam merespon benda asing yang masuk ke dalam tubuh, zat imunostimulan tersebut dapat berupa alami dan buatan (Baratawidjaja, 2002).

Kidd (2004) menegaskan bahwa zat gizi dari pakan merupakan sumber penopang kekebalan utama pada ternak unggas. Wallace et al. (2010) menjelaskan bahwa mekanisme imbuhan pakan fitogenik dalam meningkatkan kekebalan tubuh ternak dapat dijelaskan secara umum sebagai akibat dari meningkatnya kesehatan usus, sehingga ternak inang tidak terpapar oleh racun mikroba atau metabolit lain yang tidak diinginkan, 
misalnya, amonia dan amina biogenik (produk fermentasi mikroba dalam usus). Konsekuaensinya, imbuhan pakan fitogenik dapat meningkatkan kemampuan usus dalam menyerap zat nutrisi, dimana dengan demikian, membantu ternak tumbuh lebih baik di dalam potensi genetiknya. Dengan kata lain, dalam pandangan Block \& Mead (2003), penggunaan imbuhan pakan fitogenik sebagai imunostimulant, bermaksud menekan atau mengurangi efek virus dan bakteri intraseluler, mengatasi imunodefisiensi, serta merangsang pertumbuhan sel-sel pertahanan tubuh dalam sistem imunitas.

Tizard (2000) mengatakan bahwa bahan yang dapat menstimulasi sistem imun disebut biological response modifiers (BRM), dibagi menjadi dua kelompok, yaitu bahan biologis dan sintetik. Yang termasuk bahan biologis diantaranya adalah sitokin (interferon), hormon timus dan antibodi monoklonal, sedangkan bahan sintetik antara lain adalah senyawa muramil dipeptida (MDP) dan levamisol. Wiedosari (2007) menjelaskan bahwa secara prinsip, kerja sistem imun dalam menghadapi invasi bahan asing dari luar tubuh bekerja secara serempak, dengan sel limfosit T-helper (Th)CD4+ sebagai pengatur utamanya. Dengan kata lain, suseptibilitas dan resistensi hewan terhadap infeksi mikroba sangat tergantung pada aktivasi dari sel ThCD4+ yang berdiferensiasi menjadi 2 kelompok berdasarkan pola sekresi sitokin, yakni pola respon Th1 dan pola respon Th2. Tizard (2000) mengatakan bahwa sitokin merupakan protein pembawa pesan kimiawi, atau mediator komunikasi interseluler yang berperan mengendalikan respon imun baik pada sistem imunitas seluler maupun humoral.

Beberapa tanaman/herbal dan minyak essensial dilaporkan memiliki kemampuan meningkatkan kekebalan tubuh seperti ekspresi limfosit, fagositosis, modulasi sitokin dan sekresi imunoglobulin, pelepasan histamin dan sebagainya (Mahima et al., 2012). Tanaman herbal memiliki beberapa efek pada sistem kekebalan tubuh ternak melalui stimulasi dan penekanan pada indikator mekanisme pertahanan non-spesifik, humoral dan kekebalan seluler (Talazadeh et al., 2016). Kiczorowska et al. (2017) mengatakan bahwa pada ternak monogastrik, mukosa saluran pencernaan adalah garis pertahanan dalam melawan patogen.
Untuk melawan agen infeksi dan agen yang berpotensi berbahaya, sistem kompleks dari jaringan limfatik submukosa dan mukosa (GALT Gutassociated lymphoid tissue) telah berkembang di usus. GALT terdiri lebih dari $75 \%$ dari semua sel limfoid dari seluruh sistem kekebalan tubuh. Sekitar $80 \%$ dari semuanya, imunoglobulin, dan $50 \%$ limfosit diproduksi di usus. Ciri khas sistem GALT adalah produksi antibodi IgA, yang disekresikan pada permukaan mukosa, dengan fungsi utama untuk menangkap antigen, dan mencegah lintasan antigen melalui mukosa. Antigen ditangkap oleh antigen presenting cells (APC) khusus, yang mengeluarkan sitokin yang sesuai (Butler \& Sinkora, 2013; Uddin et al., 2013). Penggunaan imbuhan pakan fitogenik, sebagai immunostimulant pada ternak, dapat berkontribusi pada modifikasi morfologi dan histologi saluran pencernaan, melalui pemanjangan villi dan pendalaman bagian dalam usus, aktivasi tol-like reseptor, menangkap luminal oleh sel dendritik, atau stimulasi sel epitel dan pelepasan sitokin proinflamasi di mukosa (Kumar et al., 2014).

Frankic et al. (2009) mengatakan bahwa sistem kekebalan tubuh umumnya mendapat manfaat dari tanaman yang kaya vitamin $\mathrm{C}$, karotenoid, dan flavonoid, tanaman dengan komponen aktif tersebut yang tinggi, dapat meningkatkan aktivitas limfosit, makrofag, dan sel Natural Killer (NK), juga meningkatkan fagositosis atau merangsang sintesis interferon. Beberapa ekstrak tanaman dilaporkan memiliki efek yang positif dalam meningkatkan imunitas ayam pedaging. Polisavone dari ekstrak alfalfa, meningkatkan Imunitas ayam pedaging (Dong et al., 2007). Hikosaka et al. (2007) melaporkan bahwa aktivitas fagositik leukosit darah ayam yang diberikan ekstrak gula tebu atau fraksi kaya polifenol dari ekstrak tebu $(500 \mathrm{mg} / \mathrm{kg} /$ hari $)$ selama 3 hari berturut-turut meningkat secara nyata bila dibandingkan dengan kontrol. Tan et al. (2004) melaporkan bahwa saponin ginseng steroid dapat merangsang sistem kekebalan tubuh dengan produksi sitokin (TNF- $\alpha$, IL-2, IL6, dan INF- $\gamma$ ), limfosit dan aktivitas makrofag. Pramod-rawat et al. (2012) telah membuat daftar tanaman yang memiliki sifat sebagai immunostimulan, yaitu sebagai berikut: lidah buaya (Aloe vera); bawang 
putih (Allium sativam); seungumcho (Angelica gigas); shatavari akar (Asparagus racemosus); mimba (Azadirachta Indica); kunyit (Curcuma longa) ; malaka (Emblica officinalis); beringin india (Ficus benghalensis); daun pepe (Gymnema sylvestre); mangga (Magnifera indica) srigading (Nyctanthes Arbortristis); kemangi (Ocimum sanctum); ginseng (Panax ginseng); kemloko (Phylanthus Emblica); jarak (Ricinus communis) ; brotowali (Tinospora cordifolia); Tricosanthes dioica; pulutan (Urena lobata); ginseng india (Withania somnifera).

Ramuan tanaman obat alami (jahe merah, sambiloto, temulawak, kunyit, temuireng, daun dan buah mengkudu) sebagai imbuhan pakan (feed additives) dilaporkan mengandung zat aktif yang dapat berfungsi sebagai immunostimulant (Zainuddin et al., 2013). Bahan dari tanaman lainnya yang potensial sebagai sumber immunostimulan adalah daun jambu biji. Noer Laily et al. (2015) melaporkan bahwa senyawa polifenol dalam ekstrak daun jambu biji dapat bertindak sebagai imunostimulan yang dapat menyebabkan peningkatan sistem kekebalan tubuh. Daun jambu biji memiliki potensi besar untuk dikembangkan sebagai immunostimulant, karena pertama, banyak dan mudah tersedia. Kedua, proses ekstraksi daun jambu biji bisa dilakukan dengan mudah, dengan biaya murah. Ketiga, ekstrak daun jambu biji mengandung antioksidan tingkat tinggi (78-201 (mg BHA eqv/g), senyawa fenolik (101 mg GAE/g) dan aktivitas biologis sebagai agen imunostimulan. Berdasarkan hasil pengukuran kadar total fenol, aktivitas antioksidan dan imunostimulan, senyawa aktif daun jambu biji yang diduga memiliki aktivitas sebagai agen imunostimulan tidak hanya polifenol semata (Noer Laily et al., 2015). Shabbir et al. (2016) menyatakan bahwa ekstrak daun jambu biji memiliki efek imunostimulan pada kedua komponen sistem kekebalan tubuh yaitu imunitas seluler dan humoral.

Fitogenik bermanfaat pada peningkatan kinerja ternak unggas dan meningkatkan aktivitas kekebalan tubuh, dan potensial sebagai antiinflamasi (Acamovic \& Brooker 2005). Hashemipour et al. (2013) melaporkan bahwa suplementasi pakan dengan timol dan carvacrol meningkatkan respon imun ayam pedaging.
Mohiti-Asli \& Ghanaatparast-Rashti (2017) melaporkan hasil pengujian pada ayam pedaging bahwa titer antibodi terhadap SRBC (sheep red blood cell) meningkat dengan suplementasi 300 ppm minyak essensial oregano (Origanum vulgare subsp. Hirtum). Penggunaan imbuhan pakan bubuk ketumbar dan kunyit kering pada level $0,75 \%$ atau campuran keduanya memiliki efek immuno-modulatory pada ayam broiler dan bisa digunakan di daerah dengan risiko tinggi infeksi virus karena akan membantu memaksimalkan manfaat vaksin (Zaki et al. 2016). Attia et al. (2017) melaporkan bahwa imbuhan pakan fitogenik kunyit (Curcuma longa Linn.) dapat digunakan pada $1 \mathrm{~kg} /$ ton pakan ayam pedaging sebagai alternatif pengganti mangan oligosakarida (MOS) atau oxytetracyclines (OTC) dengan indeks efisiensi produksi dan status kesehatan ayam broiler yang tidak berbeda. Suplementasi $1 \%$ biji kelor (Moringa oleifera) di dalam pakan ayam broiler menunjukkan dampak positif pada pertumbuhan, kekebalan dan biokimia serum (Ahmad et al., 2018).

Al-Mufarrej (2014) menunjukkan bahwa suplemen biji jintan hitam pada dosis $1 \%$ atau $1,4 \%$ akan meningkatkan daya respon imun pada ayam broiler. Penambahan aditif kunyit 0,5\% berupa tepung kunyit, fermentasi ampas kunyit dan ampas kunyit dalam ransum dapat meningkatkan total leukosit, limfosit dan eosinofil namun menurunkan neutrofil pada ayam kampung super (Setiyanto et al., 2017). Begum et al. (2014) melaporkan bahwa terjadi peningkatan IgG pada broiler ketika dilakukan suplementasi $0,1 \%$ campuran herbal yang terdiri dari Phlomis umbrosa Turez, Cynancum wilfordii Hem, Zingiber officinale Rosc dan Platycodi Radix pada ransum. Laporan penelitian (Mushtaq et al., 2012; Pant et al., 2012) menunjukkan bahwa penambahan 10 atau $20 \mathrm{~g}$ ekstrak tanaman ginseng india (Withania somnifer, mengandung senyawa bioaktif withanolides (lakton steroid)) per liter air yang diberikan pada ayam broiler memiliki manfaat dalam meningkatkan hemoglobin, jumlah sel darah putih dan titer antibodi melawan penyakit virus seperti infectious bursal disease (IBD) dan infectious bronchitis yang menunjukkan peningkatan profil hematologi dan status imunologi ternak unggas. Hasil penelitian 
melaporkan bahwa penambahan 6 gram biji adas anis (Pimpinella anisum) per kilogram ransum memberikan dampak pada peningkatan titer antibodi terhadap virus penyakit newcastle desease (ND) dan infectious bronchitis (IB) pada ayam broiler (Alhajj et al., 2014).

\section{Imbuhan Pakan Fitogenik Sebagai Pemacu Pertumbuhan}

Beberapa peneliti (Stanacev et al., 2011; Dhama et al., 2014; 2015) melaporkan bahwa penggunaan imbuhan pakan fitogenik dala $\mathrm{m}$ pakan dapat meningkatkan kinerja, memperbaiki konversi pakan, dan meningkatkan keamanan dan kualitas daging yang dihasilkan. Dampak positif penggunaan imbuhan pakan fitogenik dalam meningkatkan kinerja pertumbuhan terkait dengan kemampuannya yang memiliki efek menguntungkan pada pemanfaatan zat nutrisi melalui dengan kemampuannya dalam menstimulasi enzim pencernaan seperti lipase, amilase, atau protease (Platel \& Srinivasan, 2004) serta meningkatkan ekosistem mikrobiota dengan mengkontrol bakteri patogen pada saluran pencernaan (Hashemi \& Davoodi, 2011; Jamroz et al., 2006).

Penggunaan imbuhan pakan fitogenik dalam ransum ayam pedaging sudah dilaporkan oleh beberapa peneliti, berikut adalah dosis penggunaan imbuhan pakan fitogenik yang memberikan dampak positif bagi peningkatan kinerja produksi. $0,3 \mathrm{~g} / \mathrm{kg}$ Ekstrak oregano atau ekstrak rosemary (Basmacioglu et al. 2004), 0,1 g/kg ekstrak timol atau 0,2 g/kg carvacol (Lee et al., 2003), $1 \mathrm{~g} / \mathrm{kg}$ ekstrak thyme (Sarica et al., 2005), 0,2 \% Cinnamon (Al-Kassie, 2009), 0,2 \% minyak essensial thyme (Denli et al., 2004), $1 \%$ biji jinten hitam (Khalaji et al., 2011). Untuk melihat sejauh mana dampak penggunaan imbuhan pakan fitogenik dalam meningkatkan kinerja produksi (peningkatan pertambahan bobot hidup dan efisiensi penggunaan ransum), penulis sajikan daftar pengaruh penggunaan imbuhan pakan fitogenik dalam ransum terhadap kinerja produksi ayam pedaging pada Tabel 1 . Pada daftar Tabel 1 ditunjukkan bahwa imbuhan pakan fitogenik di beberapa negara sudah diproduksi secara komersial, hal itu terlihat dari banyaknya laporan studi terkait penggunaan imbuhan pakan fitogenik komersial, dengan merek dagang tertentu, yang diujicobakan pada ransum ayam pedaging. Hal ini sebagai bukti bahwa imbuhan pakan fitogenik secara global sudah dijadikan salah satu alternatif pengganti antibiotika yang serius dikembangkan serta sudah di industrialisasi. Imbuhan pakan fitogenik komersial diproduksi dengan menggunakan bahan dari senyawa senyawa fitogenik tanaman yang umumnya mengandung minyak esensial, thymol, carvacrol, anethol, limonen, sebagai bahan aktif utama. Penggunaan imbuhan pakan fitogenik bervariasi antar setiap jenis imbuhan pakan fitogenik dengan dampak peningkatan terhadap kinerja produksi ayam broiler yang juga variatif. Daun jambu biji dan biji jintan hitam juga dilaporkan pula memiliki dampak positif bagi peningkatan kinerja produksi ayam broiler (Tabel 1).

\section{Peluang Pengembangan Imbuhan Pakan Fitogenik di Indonesia}

Secara nasional di Indonesia, dalam kurun waktu 20 tahun (1994-2015), produksi daging asal ternak unggas memiliki pertumbuhan yang lebih tinggi dibandingkan dengan daging asal ternak sapi/kerbau maupun kambing/domba, seiring dengan semakin membaiknya pendapatan masyarakat, membuat konsumsi terhadap produk peternakan cenderung turut meningkat (Priyono \& Priyanti, 2018). Secara khusus Priyono \& Priyanti (2018) meberikan penegasan bahwa daging ayam ras pedaging memiliki laju pertumbuhan yang paling tinggi sebesar $6,67 \% /$ tahun dibandingkan dengan daging lainnya. Hal ini selaras dengan industri perunggasan yang berkembang sangat pesat dalam memenuhi kebutuhan daging masyarakat dengan harga yang lebih terjangkau. Data statitika peternakan yang dikeluarkan oleh Direktorat Jenderal Peternakan dan Kesehatan Hewan, Kementerian Pertanian mencatat bahwa produksi daging dari ternak ayam pedaging secara nasional di tahun 2016 mencatat sebesar 1,9 juta ton. Besarnya data produksi daging ayam pedaging serta kenaikan produksi daging unggas dan ayam pedaging yang besar di atas, menunjukkan bahwa betapa besarnya kenaikan produksi daging unggas dan daging ayam pedaging secara nasional, dalam setiap tahunnya. Seluruh proses produksi budidaya dalam memproduksi daging unggas dan daging ayam pedaging tersebut, seluruhnya dilakukan di dalam negeri. Artinya kebutuhan dalam negeri akan alternatif pengganti antibiotika dalam pakan unggas atau ayam pedaging sangat besar adanya. 
Tabel 1. Pengaruh penggunaan imbuhan pakan fitogenik dalam ransum terhadap kinerja produksi ayam pedaging

\begin{tabular}{|c|c|c|c|c|c|}
\hline \multirow{2}{*}{ No } & \multirow{2}{*}{ Jenis tanaman/ senyawa aktif } & \multirow{2}{*}{ Dosis } & \multicolumn{2}{|c|}{$\begin{array}{c}\text { Pengaruh perlakuan } \\
\text { dibandingkan Kontrol }{ }^{1)}\end{array}$} & \multirow{2}{*}{ Pustaka } \\
\hline & & & $\begin{array}{l}\text { Pertambahan } \\
\text { Bobot Hidup }\end{array}$ & $\begin{array}{l}\text { Efisiensi } \\
\text { Penggunaan } \\
\text { Ransum }\end{array}$ & \\
\hline 1 & Minyak esensial thyme dan adas anis & $250 \mathrm{~g} / \mathrm{kg}$ & $+3,72 \%$ & $+5,75 \%$ & Cho et al., 2014 \\
\hline 2 & $\begin{array}{l}\text { Campuran oregano, adas manis dan minyak } \\
\text { esensial jeruk dengan carvacrol, anethol dan } \\
\text { limonen sebagai bahan aktif utama dan } \\
\text { frukto-oligosakarida yang bertindak sebagai } \\
\text { carrier }\end{array}$ & $\begin{array}{c}125 \\
\mathrm{mg} / \mathrm{kg}\end{array}$ & $+2,57 \%$ & $+6,75$ & $\begin{array}{c}\text { Mountzouris et al., } \\
2011\end{array}$ \\
\hline 3 & $\begin{array}{l}\text { Kombinasi dari ekstrak tanaman Foeniculum } \\
\text { vulgarae var.dulcemil; Melissa officinalis } L ; \\
\text { Mentha arvensis L.; Pimpinella anisum L.; } \\
\text { Quercus cortex; Syzy-gium aromaticum L. } \\
\text { dan Thymusvulgaris L. }\end{array}$ & $\begin{array}{c}150 \\
\mathrm{mg} / \mathrm{kg}\end{array}$ & $+6,20$ & 9,94 & Wati et al., 2015 \\
\hline 4 & $\begin{array}{l}\text { Minyak essensial dari tanaman mint } \\
\text { (Mentha arvensis), adas bintang (Illicium } \\
\text { verum) dan } \\
\text { cengkeh (Syzygium aromaticum), dicampur } \\
\text { dengan (silicium dioxide) } \\
\text { dan natrium klorida) sebagai agen pembawa. }\end{array}$ & $\begin{array}{c}100 \\
\mathrm{mg} / \mathrm{kg}\end{array}$ & $+7,5 \%$ & $+5,17 \%$ & $\begin{array}{c}\text { Paraskeuas et al., } \\
2017\end{array}$ \\
\hline 5 & $\begin{array}{l}\text { Imbuhan pakan fitogenik komersial merek } \\
\text { Bedgen } 40 \circledR \text { yang mengandung ekstrak } \\
\text { Cynara scolymus dan kolin klorida }\end{array}$ & $150 \mathrm{~g} /$ ton & $+3,8 \%$ & $+3.5 \%$ & Hassan et al., 2015 \\
\hline 6 & $\begin{array}{l}\text { Imbuhan pakan fitogenik komersial merek } \\
\text { BIOSTRONG® 510, (Austria)yang berasal } \\
\text { dari campuran minyak esensial, dengan } \\
\text { timol dan anethole sebagai zat aktif utama. }\end{array}$ & $\begin{array}{c}150 \\
\mathrm{mg} / \mathrm{kg}\end{array}$ & $+1,7 \%$ & $+3,26 \%$ & Amad et al., 2013 \\
\hline 7 & $\begin{array}{l}\text { Imbuhan pakan fitogenik komersial merek } \\
\text { Biomin PEP } 1000 \text { (Biomin }{ }^{\circledR} \text { GmbH } \\
\text { Austria) yang berasal dari minyak essesnail } \\
\text { oregano, adas manis, dan minyak jeruk }\end{array}$ & $\begin{array}{l}1000 \\
g / \text { ton }\end{array}$ & $+2,5 \%$ & $+2,8 \%$ & $\begin{array}{l}\text { Vukić-Vranješ et } \\
\text { al., } 2013\end{array}$ \\
\hline 8 & $\begin{array}{l}\text { Imbuhan pakan fitogenik komersial merek } \\
\text { Imunostart@, M Cassab (terdiri dari ekstrak } \\
\text { kunyit, ekstrak jeruk, dan ekstrak biji } \\
\text { anggur). }\end{array}$ & $\begin{array}{l}500-700 \\
\text { g/ton }\end{array}$ & $+0,65 \%$ & $+1,16 \%$ & Pelícia et al., 2013 \\
\hline 9 & $\begin{array}{l}\text { Imbuhan pakan fitogenik komersial merek } \\
\text { BIOSTRONG® 510, (Austria)yang berasal } \\
\text { dari campuran minyak esensial, dengan } \\
\text { timol dan anethole sebagai zat aktif utama. }\end{array}$ & $\begin{array}{l}1500 \\
\mathrm{mg} / \mathrm{kg}\end{array}$ & $+3 \%$ & $+7,2 \%$ & Amad et al., 2011 \\
\hline 10 & $\begin{array}{l}\text { Imbuhan pakan fitogenik komersial merek } \\
\text { Biomin PEP } 1000 \text { (Biomin }{ }^{\circledR} \text { GmbH Austria) } \\
\text { yang berasal dari minyak essesnail oregano, } \\
\text { adas manis, dan minyak jeruk }\end{array}$ & $125 \mathrm{~g} /$ ton & $+3,5 \%$ & $+2 \%$ & Peric et al., 2010 \\
\hline 11 & Biji jintan hitam & $5 \%$ & $+8,71$ & $+11,31$ & Khan et al., 2012 \\
\hline 12 & $\begin{array}{l}\text { Imbuhan pakan fitogenik komersial merek } \\
\text { BIOSTRONG® 510, (Austria) yang berasal } \\
\text { dari campuran minyak esensial, dengan } \\
\text { timol dan anethole sebagai zat aktif utama. }\end{array}$ & $\begin{array}{c}250 \\
\mathrm{mg} / \mathrm{kg}\end{array}$ & $+3,72 \%$ & $+5,75 \%$ & Cho et al., 2014 \\
\hline 13 & Daun jambu biji & $1 \%$ & $+4,18$ & $+9,09$ & $\begin{array}{l}\text { Mahmoud et al., } \\
2013\end{array}$ \\
\hline
\end{tabular}

Keterangan : ${ }^{1)}$ Mengalami kenaikan/perbaikan 


\section{Peluang Pengembangan Imbuhan Pakan Fitogenik di Indonesia}

Secara nasional di Indonesia, dalam kurun waktu 20 tahun (1994-2015), produksi daging asal ternak unggas memiliki pertumbuhan yang lebih tinggi dibandingkan dengan daging asal ternak sapi/kerbau maupun kambing/domba, seiring dengan semakin membaiknya pendapatan masyarakat, membuat konsumsi terhadap produk peternakan cenderung turut meningkat (Priyono \& Priyanti, 2018). Secara khusus Priyono \& Priyanti (2018) meberikan penegasan bahwa daging ayam ras pedaging memiliki laju pertumbuhan yang paling tinggi sebesar 6,67\%/tahun dibandingkan dengan daging lainnya. Hal ini selaras dengan industri perunggasan yang berkembang sangat pesat dalam memenuhi kebutuhan daging masyarakat dengan harga yang lebih terjangkau. Data statitika peternakan yang dikeluarkan oleh direktorat jenderal peternakan dan kesehatan hewan, kementerian pertanian mencatat bahwa produksi daging dari ternak ayam pedaging secara nasional di tahun 2016 mencatat sebesar 1,9 juta ton. Besarnya data produksi daging ayam pedaging serta kenaikan produksi daging unggas dan ayam pedaging yang besar di atas, menunjukkan bahwa betapa besarnya kenaikan produksi daging unggas dan daging ayam pedaging secara nasional, dalam setiap tahunnya. Dimana seluruh proses produksi budidaya dalam memproduksi daging unggas dan daging ayam pedaging tersebut, seluruhnya dilakukan di dalam negeri. Artinya kebutuhan dalam negeri akan alternatif pengganti antibiotika dalam pakan unggas atau ayam pedaging sangat besar adanya.

Penelitian terkait pencarian jenis tanaman yang potensial untuk digunakan sebagai bahan imbuhan pakan fitogenik sebagai pengganti antibiotika dalam pakan dilaporkan sudah cukup lama dilakukan oleh para peneliti di Indonesia, khususnya di Balai Penelitian Ternak, lembaga penelitian nasional yang memiliki mandat dalam melakukan penelitian terkait peternakan. Beberapa tanaman yang telah diteliti adalah tanaman Aloe vera (Purwadaria et al., 2001; Bintang et al., 2001; Sinurat et al., 2003; Sinurat et al., 2004; Sinurat, 2013), Curcuma xanthorrhiza (Sinurat et al., 2009), jahe merah, sambiloto, temulawak, kunyit, temuireng, daun dan buah mengkudu (Zainuddin et al., 2013). Sinurat et al. (2018) melaporkan telah melakukan kajian kemampuan dari beberapa ekstrak tanaman dalam kaitannya sebagai alternatif pengganti AGP, tanaman yang diteliti adalah daun Binahong (A. cordifolia), daun cengkeh $(S$. aromaticum), daun jambu biji (P. Guajava), biji lerak (S. rarak), kulit buah (G. mangostana), daun meniran ( $P$. Urinaria), kulit kacang mete (A. occidetale), daun Neem (A. indica), daun mindi (M. Azedarach), minyak biji kapok (C. pentandra), daun salam ( $S$. polyanthum), daun sirih ( $P$. betel) dimana di laporkan bahwa asap cair dari kulit kacang mete dan ekstrak daun cengkeh dilaporkan memiliki potensi tertinggi sebagai antioksidan, antibiotik dan anti-jamur (Sinurat et al., 2018).

Sinurat et al. (2018) mengatakan bahwa sebagian besar penelitian pencarian jenis tanaman sebagai pengganti antibiotika mempelajari efektivitas bioaktif yang diperoleh dari bahan tunggal dan hasilnya belum diterapkan dalam industri peternakan secara komersial karena beberapa faktor seperti: variabilitas pada efektivitas, biaya produksi tinggi atau terlalu mahal jika dibandingkan dengan antibiotic growth promotor (AGP) komersial, hal ini apabila dibandingkan ketika penggunaan AGP masih diperbolehkan di Indonesia. Saat ini penggunaan AGP sudah dilarang, sehingga terbuka peluang penggunaan imbuhan pakan fitogenik dalam ransum unggas serta terbukanya juga peluang untuk industrialisasi atau komersialisasi imbuhan pakan fitogenik di Indonesia.

Dalam mendukung produksi optimum ayam pedaging di Indonesia sebagai negara tropis, maka imbuhan pakan fitogenik yang diharapkan adalah, pertama, memiliki kemampuan sebagai antioksidan yang kuat untuk menghambat terjadinya stress oksidatif ketika terjadi cekaman panas akibat suhu lingkungan yang tinggi. Kedua, memiliki kemampuan sebagai immunostimulant, dalam rangka meningkatkan daya tahan tubuh ayam pedaging terutama ketika kondisi musim hujan yang rentan dengan serangan penyakit akibat dari virus, bakteri dan jamur sebagai dampak dari buruknya kondisi lingkungan. Ketiga, memiliki aktivitas sebagai anti bakteri yang kuat, untuk menunjang kesehatan saluran pencernaan usus ayam pedaging. Sehubungan kesehatan saluran 
pencernaan merupakan pangkal dari tercapainya kinerja produksi optimum serta diraihnya kesehtan ternak yang optimum pula. Karena kondisi kesehatan saluran pencernaan merupakan salah satu faktor utama dari besaran asupan zat gizi ke dalam tubuh yang memberikan bahan dalam proses metabolisme ternak untuk hidup pokok, tumbuh dan menjaga daya tahan tubuh dari serangan sumber penyakit sehingga menentukan tingkat kesehatan tubuh ternak.

Sinergisme antara lembaga penelitian dengan perusahaan komersial yang terjun dibidang industri imbuhan pakan menjadi tonggak penting dalam pengembangan produksi imbuhan pakan fitogenik secara komersial. Indutrialisasi imbuhan pakan fitogenik menjadi kata kunci yang penting sebagai solusi dalam menghadapi situasi dimana saat ini penggunaan AGP dilarang dalam pakan, sementara itu tuntutan dari pelaku industri pakan untuk segera memperoleh alternatif penggantinya yang setara dengan antibiotika, juga tuntutan dari peternak ayam pedaging agar kinerja produksi ayam pedaging peliharaannya tetap terjaga stabil setelah dilarangnya penggunaan AGP dalam pakan. Tuntutan yang lainnya adalah tuntutan terkait harus terjaminnya keamanan pangan yang dihasilkan dari ternak ayam pedaging yang digaungkan oleh pihak konsumen, terutama dari residu penggunaan antibiotika. Tuntutan-tuntutan tersebut di atas menjadikan bahwa kebutuhan imbuhan pakan alternatif pengganti AGP menjadi sangat penting dan genting adanya.

Sebagai negara yang kaya dengan biodiversitas tanaman, maka kekayaan alam Indonesia, yang diakui dunia sebagai salah satu surga bagi keanekeragaman hayati, menjadi modal utama bahwa Indonesia layak dan seharusnya mampu dalam memproduksi imbuhan pakan fitogenik dengan menggunakan bahan-bahan dari sumber daya alam lokal. Lembaga-lembaga penelitian beserta perguruan tinggi telah banyak melakukan penelitian terkait penggunaan senyawa tanaman (fitogenik) sebagai imbuhan pakan bagi ternak ayam pedaging. Hasil hasil penelitian tersebut kemudian bisa di kompilasi dan diworkshopkan dengan melibatkan pelaku industri pakan, pelaku industri imbuhan pakan, dan peternak ayam pedaging, dalam rangka mensinergikan antara kebutuhan dari pelaku industri pakan, termasuk pula industri imbuhan pakan, pihak peternak ayam pedaging dengan hasil hasil penelitian terkait penggunaan imbuhan pakan fitogenik yang sudah dicapai saat ini. Hasil penelitian terkait penggunaan imbuhan pakan fitogenik berbasis tanaman lokal yang diujicobakan pada ayam pedaging dengan kondisi pemeliharaan yang dilakukan di Indonesia lebih memiliki kekuatan landasan ilmiah bahwa bahan imbuhan pakan fitogenik tersebut potensial di gunakan oleh para peternak, sehingga potensial untuk diindustrialisasi secara komersial di Indonesia.

\section{KESIMPULAN}

Pencarian alternatif pengganti Antibiotic growth promotor (AGP) dalam pakan ayam pedaging terus dilakukan seiring dengan telah dilarangnya pengggunaan AGP dalam pakan. Beberapa hasil penelitian menunjukkan bahwa imbuhan pakan fitogenik dari berbagai jenis tanaman, potensial untuk dijadikan sebagai salah satu alternatif pengganti AGP dalam pakan ayam pedaging. Sebagai negara yang kaya dengan biodiversitas tanaman, Indonesia idealnya memiliki kemampuan dalam memproduksi imbuhan pakan fitogenik berbasis sumber daya lokal yang ada. Kondisi Indonesia sebagai negara tropis, dimana suhu udara lebih tinggi dari suhu zona nyama bagi pemeliharaan ayam pedaging, maka imbuhan pakan fitogenik yang dibutuhkan adalah yang memiliki kemampuan setidaknya sebagai antioksidan, antimikroba, dan immunostimulan yang kuat. Sinergisme antara lembaga penelitian dan perguruan tinggi dengan para pelaku industri imbuhan pakan serta pelaku industri pakan, menjadi tonggak penting dalam pengembangan imbuhan pakan fitogenik ke depan di Indonesia.

\section{DAFTAR PUSTAKA}

Abdeirahirn S.I., A.Z. Almadboul, M.E.A. Omer, \& A. Elegami. 2002. Antimicrobial activity of Psidium Guajava L. Fitoterapia 73:713715 .

Abubakar, E.M.M. 2009. The use of Psidium Guajava Linn. in treating wound, skin and soft tissue infections. Sci Res Essays 4:605611. 
Acamovic, T. \& J.D. Brooker. 2005. Biochemistry of plant secondary metabolites and their effects in animals. Proc Nutr Soc. 64:403412.

Afanas'ev I. 2010. Signaling by Reactive Oxygen and Nitrogen Species in Skin Diseases. Curr Drug Metab. 11:409-414.

Ahmad, S., A. Khalique, T.N. Pasha, S. Mehmood, K. Hussain, S. Ahmad, B. Rasheed, M.M. Awais, \& S.A. Bhatti. 2018. Influence of Feeding Moringa oleifera Pods as Phytogenic Feed Additive on Performance, Blood Metabolites, Chemical Composition and Bioactive Compounds of Breast Meat in Broiler'. Kafkas Univ Vet Fak Derg 24(2):195-202.

Aksit, M., E. Goksoy, F. Kok, D. Ozdemir, \& M. Ozdogan. 2006. The impacts of organic acid and essential oil supplementations to diets on the microbiological quality of chicken carcasses. Arch Geflugelkd 70: 168-173.

Al- Yasiry, A.R.M. \& B. Kiczorowska. 2016. Frankincense therapeutic properties. Postep Hig Med Dosw 70:380-391.

Al-Hajj, N., H.X. Oaid Wang, Ma C, Lou, Z. Bashari, \& M.R. Thabit. 2014. Antimicrobial and antioxidant activities of the essential oils of some aromatic medicinal plants (Pulicariainuloides- Asteraceae and Ocimumforskolei- Lamiaceae). Trop $J$ Pharm Res. 13 (8):1287-1293.

Al-Kassie, G.A. 2009. Influence of two plant extracts derived from thyme and cinnamon on broiler performance. Pak Vet J. 29(4): 169-173.

Al-Mufarrej, S.I. 2014. Immune-responsiveness and performance of broiler chickens fed black cumin (Nigella sativa L.) powder. Journal of the Saudi Society of Agricultural Sciences 13:75-80.

Amad, A.A., K. Manner, K.R. Wendler, K. Neumann, \& J. Zentek. 2011. Effects of a phytogenic feed additive on growth performance and ileal nutrient digestibility in broiler chickens. Poult Sci. 90:2811-2816.

Amad, A.A., K.R. Wendler, \& J. Zentek. 2013. Effects of a phytogenic feed additive on growth performance, selected blood criteria and jejunal morphology in broiler chickens. Emir. J Food Agric. 25(7):549-554.

Ambrožič Avguštin J. 2012. Animal production systems as a selective environment for antibiotic resistance genes. Acta Agric Slov. 100(1):7-17.

Applegate, T.J., V. Klose, T. Steiner, A. Ganner, \& G. Schatzmayr. 2010. Probiotics and phytogenics for poultry: myth or reality? J Appl Poult Res. 19:194-210.

Arima, H. \& G. Danno. 2002. Isolation of antimicrobial compounds from guava (Psidium guajava L.). Biosci Biotechnol Biochem. 66:1727-1730.

Ariyanto, A.N., N. Iriyanti, \& M. Mufti. 2013. Pemanfaatan tepung kunyit (Curcuma domestica Val) dan sambiloto (Andrographis paniculata Nees) dalam pakan terhadap konsumsi pakan dan pertumbuhan bobot badan broiler. JIP 1(2): 471-478.

Athanasiadou, S., J. Githiori, \& I. Kyriazakis. 2007. Medicinal plants for helminthes parasite control: facts and fiction. Animal. 1(9):1392-1400.

Attiaa, Y.A., M.A. Al-Harthia, \& S.S. Hassan. 2017. Turmeric (Curcuma longa Linn.) as a phytogenic growth promoter alternative for antibiotic and comparable to mannan oligosaccharides for broiler chicks. Rev Mex Cienc Pecu. 8(1):11-21.

Baratawidjaja, K.G. 2002. Imunologi Dasar. Fakultas Kedokteran Universitas Indonesia. Jakarta.

Barreto, M.S.R., J.F.M. Menten, A.M.C. Racanicci, P.W.C. Pereira, \& P.V. Rizzo. 2008. Plant Extracts used as Growth Promoters in Broilers. Bra J Poult Sci. 10:109-115.

Basmacioglu, H., O. Tokusoglu, \& M. Ergul. 2004. The effect of oregano and rosemary essential oils or alphatocopheryl acetate on performance and lipid oxidation of meat enriched with n-3 PUFAs in broilers. S Afr J Anim Sci. 34: 197-210. 
Becker, G.S. 2010. Antibiotic use in agriculture: background and legislation. Congressional Research Service, 7-5700, R40739. CRS Report for Congress. January 7, 2010.

Becker, P.M. \& S. Galletti. 2008. Food and feed components for gut health-promoting adhesion of E. coli and Salmonella enterica. J Sci Food Agric. 88:2026-2035.

Bedford, M.R. \& A.J. Cowieson. 2012. Exogenous enzymes and their effects on intestinal microbiology. Anim Feed Sci Technol. 173: 76-85.

Begum, M., M.M. Hossain, \& I.H. Kim. 2014. Effects of the plant extract YGF251 on growth performance, meat quality, relative organ weight, nutrient digestibility and blood profiles in broiler chickens: possible role of insulin-like growth factor. Vet Med. 59(9):415-423

Bell, D.D. \& W.D. Weaver. 2002. Commercial Chicken Meat and Egg Production. Academic Pub-lisher, United States of America.

Ben Arfa A., S. Combes, L. Preziosi-Belloy, N. Gontard, \& P. Chalier. 2006. Antimicrobial activity of carvacrol related to its chemical structure. Lett Appl Microbiol. 43:149-154.

Bintang I.A.K., A.P. Sinurat, T. Purwadaria, M.H. Togatorop, J. Rosida, H. Hamid, \& Saulina. 2001. Pengaruh pemberian bioaktif dalam lidah buaya (Aloevera) terhadap penampilan ayam broiler. Balai Penelitian Ternak. Bogor.

Bintarti, T. 2014. Skrining fitokimia dan uji kemampuan sebagai antioksidan dari daun jambu biji (Psidium guajava. L). PANNMED 9(1):40-44.

Bird, N.A., P. Hunton, W.D. Morrison, \& L.J. Weber. 2003. Heat stress in cage layer. Ministry of Agriculture and Food. Ontario (Canada).

Biswas, B., K. Rogers, F. McLaughlin, D. Daniels, \& A. Yadav. 2013. Antimicrobial activities of leaf extract of Guava (Psidium guajava $\mathrm{L}$ ) on Two Gram-Negatif and Gram-Positiv Bacteria. Int J Microbiol. Article ID 746165.
Block, K.I. \& M.N. Mead. 2003. Immune system effects of Echinaceae, Ginseng and Astragalus: A review. ICT 2(3):247-267.

Botham, K.M. \& P.A. Mayes. 2009. The repiratory chain \& Oxidative Phosphorilation. In: Murray K, Bender DA, Botham KM, et al. Eds. Harper's Illuustrated Biochemistry, Ed 28th Mc Graw Hill Lange. 103-12.

BPS. 2017. Suhu minimum rata-rata dan maksimum di stasiun pengamatan BMKG oc 2011-2015. https://www.bps.go.id/tatictable/ 2017/02/09/1961/suhu-minimum-rata-ratadan-maksimum-di-stasiun-pengamatanbmkg-oc-2011-2015.html (9 April 2019).

Burt S. 2004. Essential oils: the iranti bacterial properties and potential applications in foods - a review. Int J Food Microbiol. 94:223-53.

Butler, J.E. \& M. Sinkora. 2013. The enigma of the lower gut-associated lymphoid tissue (GALT). J Leukocyte Biol. 94:259-270.

Chen, K.C., C.L. Hsieh, K.D. Huang, Y.B. Ker, C.C. Chyau, \& R.Y. Peng. 2009. Anticancer activity of rhamnoallosan against DU-145 cells is kinetically complementary to coexisting polyphenolics in Psidium guajava budding leaves. J Agric Food Chem. 57: 6114-6122.

Chirag, P.J., S. Tyagi, N. Halligudi, J. Yadav, S. Pathak, S.P. Singh, A. Pandey, D.S. Kamboj, \& P. Shankar. 2013. Antioxidant activity of herbal plants: a recent review. JDDT 1(8):01-08.

Chludil, H.D., G.B. Corbino, \& S.R. Leicarh. 2008. Soil quality effects on chenopodium album flavonoid content and antioxidant potential. J Agric Food Chem. 56(13):50505056.

Cho, J.H., H.J. Kim, \& I.H. Kim. 2014. Effects of phytogenic feed additive on growth performance, digestibility, blood metabolites, intestinal microbiota, meat color and relative organ weight after oral challenge with Clostridium perfringens in broilers. Livest Sci. 160:82-88.

Choi, S.C., S.L. Ingale, J.S. Kim, Y.K. Park, I.K. Kwon, \& B.J. Chae. 2013. An antimicrobial peptide-A: Effects on growth performance, 
nutrient retention, intestinal and faecal microflora and intestinal morphology of broilers. Br Poult Sci. 54:738-746.

Chrpová, D., L. Kourimská, M.H. Gordon, V. Heřmanová, I. Roubičková, \& J. Panek. 2010. Antioxidant activity of selected phenols and herbs used in diets for medical conditions. Czech J Food Sci. 28(4):317325 .

Cross, D.E., R.M. McDevitt, K. Hillman, \& T. Acamovic. 2007. The effect of herbs and their associated essential oils on performance, dietary digestibility and gut microflora in chickens from 7 to 28 days of age. Brit Poultry Sci. 48:496-506.

Dahiya, J.P., D. Hoehler, D.C. Wilkie, A.G. Van Kessel, \& M.D. Drew. 2005. Effect of dietary glycine on intestinal Clostridium perfringens populations and a-toxin production in broiler chickens. Poult Sci. 84:94.

De Lange, C.F.M., J.R. Pluske, J. Gong, \& C.M. Nyachoti. 2010. Strategic use of feed ingredients and feed additives to stimulate gut health and development in young pigs. Livest Sci. 134:124-134.

Delaquis, R.J., K. Stanich, B. Girard, \& G. Massa. 2002. Anti-microbial activity of individual and mixed fractions of dill, cilantro, coriander and eucalyptus essential oils. Int $\mathbf{J}$ Food Microbiol. 74:101-109.

Denli, M., F. Okan, \& A.N. Uluocak. 2004. Effect of dietary supplementation of herb essential oils on the growth performance, carcass and intestinal characteristics of quail (Coturnixcoturnix japonica). S Afr J Anim Sci. 34:174-179.

Dhama, K., S. Chakraborty, R. Tiwari, A.K. Verma, M. Saminathan, Y.S. Amarpalmalik, Z. Nikousefat, M. Javdani, \& R.U. Khan. 2014. A concept paper on novel technologies boosting production and safeguarding health of humans and animals. Res Opin Anim Vet Sci. 4:353-370.

Dhama, K., S.K. Latheef, S. Manis, H.A. Samad, K. Kartik, R. Tiwari, R.U. Khan, M. Alagawany, M.R. Farag, G.M. Alam, Laudadio
V, Tu \& V. Farelli. 2015. Multiple beneficial applications and modes of action of herbs in poultry health and production A review. Int J Pharmacol. 11:152-176.

Dibner, J.J. \& J.D. Richards. 2005. Antibiotic growth promoters in agriculture: History and mode of action. Poult Sci. 84:634-643.

Dong, X.F., W. Gao W.W., J.M. Tong, H.Q. Jia, R.N. Sa, \& Q.. 2007. Effect of polysavone (alfalfa extract) on abdominal fat deposition and immunity in broiler chickens. Poult Sci. 86:1955-1959

Dragan, L., A. Gyorke, J.F. Ferreira, I.A. Pop, I. Dunca, M. Dragan, V. Mircean, I. Dan, \& V. Cozma. 2014. Effects of Artemisia annua and Foeniculum vulgare on chickens highly infected with Eimeria tenella (Phylum Apicomplexa). Acta Vet Scand. 56(22).

Erf, G.F. 2004. Cell-mediated immunity in poultry. Poult Sci. 83:580-590.

Faleiro, M.L. 2011. The mode of antibacterial action of essential oils. In Science Against Microbial Pathogens: Communicating Current Research and Technological Advances; Mendez-Villas, A., Ed.; Formatex: Badajoz, Spain. pp. 1143-1156.

Farag, M.R., M. Alagawany, \& V. Tufarelli. 2016. In vitro antioxidant activities of resveratrol, cinnamaldehyde and their synergistic effect against cyadox-induced cytotoxicity in rabbit erythrocytes. Drug Chem Toxicol. 17:1-10.

Fascina, L., J.R. Sartori, F.B. Carvalho, L.A. Pereira, A.S. Carrijo, \& P.C. Araujo. 2010. Digestibilidade de nutrientes da dieta em frangos de corte alimentado scom aditivos fitogênicos e ácidos orgânicos na fase de crescimento [cd rom]. Anais da Conferência APINCO de Ciência e Tecnologia Avícolas. Campina: FACTA. Santos, São Paulo. Brasil.

Fascina, L., J.R. Sartori, E. Gonzales, F.B. Carvalho, G.V. Polycarpo, \& I.M.G.P. Souza. 2012. Phytogenic additives and organic acids in broiler chicken diets. R Bras Zootec. 41(10):2189-2197. 
Frankic, T., M. Voljg, J. Salobir, \& V. Rezar. 2009. Use of herbs and spices and their extracts in animal nutrition. Acta Agric Slov. 92:95-102.

Ganguly, S. 2013. Phytogenic Growth Promoter as Replacers for Antibiotic Growth Promoter in Poultry Birds. Adv Pharmacoepidem Drug Safety. 2:e119.

García, V., P. Catalá-Gregori, F. Hernández, M.D. Megías, \& J. Madrid. 2007. Effect of formic acid and plant extracts on growth, nutrient digestibility, intestine mucosa morphology, and meat yield of broilers. J Appl Poult Res. 16:555-562.

Geidam, Y.A., H. Usman, M. Abubakar, \& B. Ibrahim. 2007. Effects of aqueous leaf extracts of Psidium guajava on bacteria isolated from the navel of day-old chicks. Res J Microb. 2:960-965.

Giannenas, I.A. \& I. Kyriazakis. 2009. Phytobased products for the control of intestinal diseases in chickens in the post antibiotic era. In: Phytogenics in animal nutrition: natural concepts to optimize gut health and performance, Steiner T. (ed.). Nottingham University Press, UK, pp. 61-85.

Gibson, G.R., H.M. Probert, J.V. Loo, R.A. Rastall, \& M.B. Roberfroid. 2004. Dietary modulation of the human colonic microbiota: Updating the concept of prebiotics. Nutr Res Rev. 17:259-275.

Gong, J., F. Yin, Y. Hou, \& Y. Yin. 2014. Chinese herbs as alternatives to antibiotics in feed for swine and poultry production: Potential and challenges in application. Can J Anim Sci. 94:223-241.

Gopi, M., K. Karthik, H.V. Manjunathachar, P. Tamilmahan, M. Kesavan, M. DashPrakash, B.L. Balaraju, \& M.R. Purushothaman. 2014. Essential oils as a feed additive in poultry nutrition. Adv Anim Vet Sci. 2:1-7.

Grashorn, M.A. 2010. Use of phytobiotics in broiler nutrition - an alternative to in feed antibiotics?. J Anim Feed Sci. 19:338-347.

Hafni, W., D. Pujiastuti, \& W. Harjupa. 2015. Analisis variabilitas temperatur udara di daerah Kototabang periode 2003-2012. J Fisika Unand 4(2):185-192.

Haida, K.S., A. Baron, \& K.S. Haida. 2011. Phenolic compounds and antioxidant activity of two varieties of guava and rue. Rev Bras CiêncSaúde. 28:11-19.

Hashemi, S.R. \& H. Davoodi. 2011. Herbal plants and their derivatives as growth and health promoters in animal nutrition. Vet Res Commun. 35:169-180.

Hashemi, S.R., I. Zulkifli, M.H. Bejo, A. Farida, \& M.N. Somchit. 2008. Acute toxicity study and phytochemical screening of selected herbal aqueous extract in broiler chickens. Int J Pharmacol. 4:352-360.

Hashemipour, H., H. Kermanshahi, A. Golian, \& T. Veldkamp. 2013. Effect of thymol and carvacrol feed supplementation on performance, antioxidant enzyme activities, fatty acid composition, digestive enzyme activities, and immune response in broiler chickens. Poult Sci. 92:2059-2069.

Hassan, H.M.A., A.W. Youssef, H.M. Ali, \& M.A. Mohamed. 2015. Adding phytogenic material and/or organic acids to broiler diets: effect on performance, nutrient digestibility and net profit. Asian J Poult Sci. 9(2):97105.

Hidetoshi, A. \& G. Danrio. 2002. Isolation of antimi-crobial compounds from guava (Psidium guajava L.) and their structural elucidation. Biosci Biotech. Biochem. 66:1727- 1730 .

Hikosaka, K., M. El-Abasy, Y. Koyama, M. Motobu, K. Koge, T. Isobe, C.B. Kang, H. Hayashidani, T. Onodera, P.C. Wang, M. Matsumura, \& Y. Hirota. 2007. Immunostimulating effects of the polyphenol-rich fraction of sugar cane (Saccharum officinarum L.) extract in chickens. Phytother Res. 21(2):120-5.

Huang, C.S., M.C. Yin, \& L.C. Chiu. 2011. Antihyperglycemic and antioxidative potential of Psidium guajava fruit in Streptozotocin- induced diabetic rats. Food Chem Toxicol. 49:2189-2195. 
Huyghebaert, G., R. Ducatelle, \& F. Van Immerseel F. 2011. An update on alternatives to antimicrobial growth promoters for broilers. Vet J. 187:182-188.

Izyumov, D.S., L.V. Domnina, \& O.K. Nepryakhina. 2010. Mitochondria as Source of Reactive Oxygen Species under Oxidative Stress. Study with Novel Mitochondria Targeted Antioxidants the "Skulachev Ion" Derivatives. Biochem (Mosc). 75(2):123129.

Jacela, J.Y., J.M. DeRouchey, M.D. Tokach, R.D. Goodband, D. Robert, J.L. Nelssen, D.G. Renter, \& S.S. Dritz. 2010. Feed additives for swine: Fact sheets flavors and mold: inhibitors, mycotoxin binders, and antioxidants. JSHAP 18(1):27-32.

Jamroz, D., A. Wiliczkiewicz, T. Wertelecki, J. Orda, \& J. Scorupinska. 2005. Use of active substances of plant origin in chicken diets based on maize and domestic grains. $\mathrm{Br}$ Poult Sci. 46:485-93.

Jugl-Chizzola, M., J. Spergser, F. Schilcher, J. Novak, A. Bucher, C. Gabler, W. Hagmuller, \& K. Zitterleglseer. 2005. Effects of Thymus vulgaris L. as feed additive in piglets and against haemolytic Ecoli in vitro. Berl Munch Tierarztl 118:495501.

Kaneria, M. \& S. Chanda. 2011. Phytochemical and Pharmacognostic Evaluation of Leaves of Psidium Guajava L. (Myrtaceae). Pharmacognos 23:32-41.

Karaskova, K., P. Suchy, \& E. Strakova. 2015. Current use of phytogenic feed additives in animal nutrition: a review. Czech J Anim Sci. 60 (12):521-530. DOI:10.17221/8594CJAS.

Khalaji, S., M. Zaghari, K.H. Hatami, S. HedariDastjerdi, L. Lotfi, \& H. Nazarian. 2011. Black cumin seeds, Artemisia leaves (Artemisia sieberi), and Camellia L. plant extract as phytogenic products in broiler diets and their effects on performance, blood constituents, immunity, and cecal microbial population. Poultry Science 90(11):25002510 .
Khan, S.H., J. Ansari, A.U. Haq, \& G. Abbas. 2012. Black cumin seeds as phytogenic product in broiler diets and its effects on performance, blood constituents, immunity and caecal microbial population. Ital J Anim Sci.11 e77:438-444.

Kiczorowska, B., W. Samolińska, A.R.M. AlYasiry, P. Kiczorowski, \& A. WiniarskaMieczan. 2017. The natural feed additives as immunostimulants in monogastric animal nutrition - a review. Ann Anim Sci. 17(3):605-625.

Kiczorowska, B., R. Klebaniuk, M. Bakowski, A.R.M. Yasiry. 2015. Culinary herbs nutritive value and content of minerals. $\mathbf{J}$ Elem. 20:599-608.

Kidd, M.T. 2004. Nutritional modulation of immune function in broilers. Poult Sci. 83:650-657.

Kompiang, I.P. 2009. Pemanfaatan mikroorganisme sebagai probiotik untuk meningkatkan produksi ternak unggas di Indonesia. JPIP 2(3):177-191.

Kris-Etherton, P.M., M. Lefevre, G.R. Beecher, M.D. Gross, C.L. Keen, \& T.D. Etherton. 2004. Bioactive compounds in nutrition and health-research methodologies for establishing biological function: The antioxidant and anti-inflammatory effects of flavonoids on atherosclerosis. Annu Rev Nutr. 24:511-538.

Kumar, M., V. Kumar, D. Roy, R. Kushwaha, \& S. Vaiswani. 2014. Application of herbal feed additives in animal nutrition - a review. Int $\mathbf{J}$ Livest Res. 4:1-8.

Kumar, V.M.H. \& Y.K. Gupta. 2003. Effect of Centella asiatica on cognition and oxidative stress in an intracerebroventricular streptozotocin model of Alzheimers disease in rat. Clin Exp Pharmacol Physiol. 30:336342.

Kusnadi, E. 2008. Peredaman cekaman oksidatif ayam broiler yang diberi antanan (Centella asiatica) dan vitamin $\mathrm{C}$ serta kaitannya dalam menurunkan kadar lemak karkas dan kolesterol plasma. JITV 13(1):1-6.

Lacroix, M. \& F. Chiasson. 2004. The influence of MAP condition and active compounds on 
the radiosensitization of Escherichia coli and Salmonella typhi present in chicken breast. Radiat Phys Chem. 71:69-72.

Laguerre, M., J. Lacomte, \& P. Villeneuve. 2007. Evaluation of the ability of antioxidants to counteract lipid oxidation: existing methods, new trends and challenges. Prog Lipid Res. 46:244-282

Lambert, R.J.W., P.N. Skandamis, P.J. Coote, \& G.J.E. Nychas. 2001. A study of the minimum inhibitory concentration and mode of action of oregano essential oil, thymol and carvacrol. Appl Microbiol. 91:453-462.

Lara, L.J. \& M.H. Rostagno. 2013. Impact of heat stress on poultry production. Animals. 3:356-369.

Lee, K.W., H. Everts, H.J. Kappert, M. Frehner, R. Losa, \& A.C. Beyen. 2003. Effects of dietary essential oil components on growth performance, digestive enzymes and lipid metabolism in female broiler chickens. Bri Poult Sci. 44: 450-457.

Lee, W.C., R. Mahmud, S. Pillai, S. Perumal, \& S. Ismail. 2012. Antioxidant Activities of Essential Oil of Psidium guajava L. Leaves. APCBEE Procedia. 2:86-91.

Li, P., X. Piao, X. Han, L. Xue, \& H. Zhang. 2012. Effects of adding essential oil to the diet of weaned pigs on performance, nutrient utilization, immune response and intestinal health. Asian-Australas J Anim Sci. 25: 1617-1626.

Li, S.Y., Y.J. Ru, M. Liu, B. Xu, A. Peron, \& X.G. Shi. 2012. The effect of essential oils on performance, immunity and gut microbial population in weaner pigs. Livest Sci. 145:119-123.

Limsong, J., K.E. Benjavong, \& J. Kuvataanasuchati. 2004. Inhibitory effects of some herbal extracts on adherence of $S$. mutans. J Ethnopharmcol. 92(2-3):281-289.

Lin, H., D. Eddy, \& B. Johan. 2006. Acute heat stress induces oxidative stress in broiler chickens. Comp Biochem Physiol. A 144: 11-17.
Lin, J., A.A. Hunkapiller, A.C. Layton, Y.J. Chang, \& K.R. Robbins. 2013. Response of intestinal microbiota to antibiotic growth promoters in chickens. Foodborne Pathog Dis. 10:331-337.

Lin, J., T. Puckree, \& T.P. Mvelase. 2002. Antidiarrhoeal evaluation of some medicinal plants used by Zulu traditional healers. J Ethnopharmacol 79(1):53-56.

Madrigal-Carballo, S., G. Rodriguez, C.G. Krueger, M. Dreher, \& J.D. Reed. 2009. Pomegranate (Punicagranatum) supplements :authenticity, antioxidant and polyphenol composition. J Funct Foods. 1:324-329.

Magdalena, S., G.H. Natadiputri, F. Nailufar, \& T. Purwadaria. 2013. Pemanfaatan produk alami sebagai pakan fungsional. Wartazoa. 23(1):31-40.

Mahima, A. Rahal, R. Deb, S.K. Latheef, Abdul Samad H, R. Tiwari, A.K. Verma, A. Kumar, \& K. Dhama. 2012. Immunomodulatory and therapeutic potentials of herbal, traditional/indigenous and ethnoveterinary medicines. Pak J Biol Sci. 15(16):754-74.

Mahmoud, R.E., I. Doaa, \& M.E. Badawi. 2013. Effect of supplementation of broiler diets with guava leaves and/or olive oil on growth, meat composition, blood metabolites and immune response. Benha Vet Med J. 25(2):23-32.

Manosroi, J., P. Dhumtanom, \& A. Manosroi, 2006. Anti-proliferative activity of essential oil extracted from Thai medicinal plants on KB and P38 cell lines. Cancer Lett. 235(1 8):114-120.

Máthé, Á. \& I. Máthé. 2008. Quality Assurance of Cultivated and Gathered Medicinal Plants. Acta Hor. 765:67-76.

Mathlouthi, N., T. Bouzaienne, T. Oueslati, F. Recoquillay, M. Hamdi, \& M. Urdaci. 2012. Use of rosemary, oregano, and commercial blend of essential oils in broiler chickens: Invitro anti microbial activities and effects on growth performance. J Anim Sci. 90:81323. 
Maulana, E.A., I.A.R.A. Asih, M. \& Arsa. 2016. Isolasi dan uji aktivitas antioksidan senyawa flavonoid dari ekstrak daun jambu biji putih (Psidium guajava Linn). Jurnal Kimia. 10(1): 161-168.

Mcreynolds, J., C. Waneck, J. Byrd, K. Genovese, S. Duke, \& D. Nisbet. 2009. Efficacy of multistrain direct-fed microbial and phytogenetic products in reducing necrotic enteritis in commercial broilers. Poult Sci. 88:2075-2080.

Miguel, F., C. Francis, \& R. François. 2009. Effet de l'utilisation de complexes d'extraits vegetaux chez le poulet en croissance, vaccine contre la coccidiose et challenge par une inoculation coccidienne a 14 jours. Huitièmes Journées de la Recherche Avicole; St Malo. France.

Milanov, D.S., D.B. Ljubojević, I.S. Čabarkapa, \& N.Z. Aleksić. 2016. Impact of antibiotics used as growth promoters on bacterial resistance. Food Feed Res. 43(2):83-92.

Mitsch, P., K. Zitterl-Eglseer, B. Kohler, C. Gabler, R. Losa, \& I. Zimpernik. 2004. The effect of two different blends of essential oil components on the proliferation of Clostridium perfringens in the intestines of broiler chickens. Poult Science 83:669-675.

Modi, C.M., S.K. Mody, H.B. Patel, G.B. Dudhatra, A. Kumar, \& T.J. Sheikh. 2011. rowth promoting use of antimicrobial agents in animals. J Appl Pharm Sci. 1(8):33-36.

Mohiti-Asli, M. \& M. Ghanaatparast-Rashti. 2017. Comparison of the effect of two phytogenic compounds on growth performance and immune response of broilers. J Appl Anim Res. 45(1):603-608.

Mountzouris, K.C., V. Paraskevas, P. Tsirtsikos, I. Palamidi, T. Steiner, G. Schatzmayr, \& K. Fegeros. 2011. Assessment of a phytogenic feed additive effect on broiler growth performance, nutrient digestibility and caecal microflora composition. Anim Feed Sci Tech. 168:223-231.

Mountzouris, K.C., V. Paraskevas, \& K. Fegeros. 2010. Phytogenic compounds in broiler nutrition. In: Steiner T, editor. Phytogenics in Animal Nutrition: Natural Concepts to Optimize Gut Health and Performance. Nottingham University Press. Nottingham, UK. pp. 97-110.

Mujahid, A., Y. Yoshiki, Y. Akiba, \& M. Toyomizu. 2005. Superoxide radical production in chicken skeletal muscle induced by acute heat stress. Poult Science 84:307-314.

Murugesan, G.R., B. Syed, S. Haldar, \& C. Pender. 2015. Phytogenic feed additives as an alternative to antibiotic growth promoters in broiler chickens. Front Vet Sci. 2(21):1-6.

Musa, H.H., S.L. Wu, C.H. Zhu, H.I. Seri, \& G.Q. Zhu. 2009. The potential benefits of probiotics in animal production and health. $\mathrm{J}$ Anim Vet Adv. 8:313-321.

Mushtaq, M., F.R. Durrani, N. Imtiaz, U. Sadique, A. Hafeez, S. Akhtar, \& S. Ahmad. 2012. Effect of administration of Withania somnifera on some hematological and immunological profile of broiler chicks. Pak Vet J. 32(1):70-72.

Muthusamy, N. \& V. Sankar. 2015. Phytogenic compounds used as a feed additives in poultry production. Int $\mathrm{J}$ Environ Sci Te. 4 (1):167-171

Noer Lailya, R.W. Kusumaningtyasa, I. Sukartia, \& M.R.D.K. Rini. 2015. The Potency of Guava Psidium Guajava (L.) Leaves as a Functional Immunostimulatory Ingredient. Procedia Chem. 14:301-307.

Oyuntseteg, N., M.A. Khasnatinov, P. MolorErdene, J. Oyunbileg, A.V. Liapu-nov, G.A. Danchinova, S. Oldokh, J. Baigalmaa, \& C. Chidragchaa. 2014. Evaluation of direct antiviral activity of the Deva-5 herb formulation and extracts of five Asian plants against influenza A virus H3N8. BMC Compl Alt Med. 14:235.

Pant, M., T. Ambwani, \& V. Umapathi. 2012. Antiviral activity of ashwagandha extract on infectious bursal disease virus replication. Indian J Sci Technol. 5(5): 2750-2751.

Paraskeuas, V., K. Fegeros, I. Palamidi, C. Hunger, \& K.C. Mountzouris. 2017. Growth performance, nutrient digestibility, antioxidant capacity, blood biochemical 
biomarkers and cytokines expression in broiler chickens fed different phytogenic levels. Anim Nutr. 3:114-120.

Patil, K.R. \& C.R. Patil. 2016. Anti-inflammatory activity of bartogenic acid containing fraction of Barringtonia racemosa Roxb in acute and chronic animal models of inflammation. J Trad Compl Med. 2(1).

Pelícia, V.C., A.C. Stradiotti, P.C. Araujo, M.K. Maruno, F.B. Carvalho, A.C. Pezzato, \& J.R. Sartori. 2013. Phytogenic Additives and Glutamine Plus Glutamic Acid in Broiler Diets. Braz J Poult Sci. 15(4):295300.

Penalver, P., B. Huerta, C. Borge, R. Astorga, R. Romero, \& A. Perea. 2005. Antimicrobial activity of five essential oils against origin strains of the Enterobacteriaceae family. APMIS 113:1-6.

Perić, L., N. Milošević, D. Žikić, S. Bjedov, D. Cvetković, S. Markov, M. Mohnl, \& T. Steiner. 2010. Effects of probiotic and phytogenic products on performance, gut morphology and cecal microflora of broiler chickens. Archiv Tierzucht. 53(3):350-359.

Perić, L., D. Žikić, \& M. Lukić. 2009. Application of Alternative Growth Promoters in Broiler Production. Biotechnol Anim Hus. 25(56):387-397.

Pham-Huy, L.A., H. He, \& C. Pham-Huy. 2008. Free radicals, antioxidants in disease and health. Int J Biomed Sci. 4(2):89-96.

Platel, K. \& K. Srinivasan. 2004. Digestiv estimulant action of spices: amythor reality?. Indian J Med Res. 119:167-79.

Pramod-Rawat, Shivani, \& Jigisha-Anand. 2012. Immunomodulatory properties of some herbal plants against Candida bicans: a review. Biot Int. 5(2):52-68.

Pratikno, H. 2010. Pengaruh ekstrak kunyit (Curcuma domestica Vahl) terhadap bobot badan ayam broiler (Gallus Sp). BAF 18(2): $39-46$.

Priyono \& A. Priyanti. 2018. Perspektif perkembangan ketersediaan produksi sumber protein asal ternak di Indonesia. Wartazoa 28(1):23-32.

Purwadaria, T., M.H. Togatorop, A.P. Sinurat, J. Rosida, S. Sitompul, H. Hamid, \& T. Pasaribu. 2001. Identifikasi zat aktif beberapa tanaman (Lidah Buaya, Mimba dan Bangkudu) yang potensial. Balai Penelitian Ternak. Bogor.

Qian, H. \& V. Nihorimbere. 2004. Antioxidant power of phytochemicals from Psidium guajava leaf. J Zhejiang Univ Sci. 5(6):67683.

Rahman, I. 2003. Oxidative stress, chromatin remodelling and gene transcription in inflammation and chronic lung desease. $\mathbf{J}$ Biochem Mol Biol. 36:95-109.

Randrianarivelo, R., P. Danthu, C. Benoit, P. Ruez, M. Raherimandimby, \& S. Starter. 2010. Novel alternative to antibiotics in shrimp hatchery: Effects of the essential oil of Cinnamosma fragrans on survival and bacterial concentration of Penaeus monodon larvae. J Appl Microbiol. 109:642-650.

Renaudeau, D., A. Collin, S. Yahav, V. De Basilio, J.L. Gourdine, \& R.J. Collier. 2012. Adaptation to hot climate and strategies to alleviate heat stress in livestock production. Animal 6:707-728.

Richards, J.D., J. Gong, \& C.F.M. de Lange. 2005. The gastrointestinal microbiota and its role in monogastric nutrition and health with an emphasis on pigs: Current understanding, possible modulations, and new technologies for eco-logical studies. Can J Anim Sci. 85. 421-435.

Rivai, H., L. Putriani, \& Mahyuddin. 2010. Karakterisasi flavonoid antioksidan dari daun jambu biji (Psidium guajava L.). J Farmasi Higea 2(2):127-136.

Rocha. M., A.H. Mijares, K.G. Malpartida, C. Banuls, L. Bellod, \& V.M. Victor. 2010. Mitochondria-Targeted Antioxidant Peptides. Current Pharmaceutical Design 16:31243131.

Ryu, N.H., K.R. Park, S.M. Kim, H.M. Yun, \& D. Nam. 2012. A hexane fraction of guava leaves (Psidium guajava L.) induces 
anticancer activity by suppressing AKT/mammalian target of rapamycin/ ribosomal kinase in human prostate cancer cells. J Medicinal Food. 15: 231-241.

Sahin, K., M. Onderci, N. Sahin, M.F. Gursu, M.F. Gursu, \& O. Kucuk. 2006. Effects of lycopene supplementation on antioxidant status, oxidative stress, performance and carcass characteristics in heat-stressed japanese quail. J Therm Biol. 31: 307-312.

Sahin, K., C. Orhan, M.O. Smith, \& N. Sahin. 2013. Moleuclar targets of dietary phytochemicals for the allevation of heat stress in poultry. World's Poult Sci. J. 69: 113-123.

Sahin, N., F. Akdemir, C. Orhan, O. Kucuk, A. Hayirli, \& K. Sahin. 2008. Lycopene enriched quail egg as functional food forhumans. Food Res Int. 41:295-300.

Sahin, N., K. Sahin, M. Onderci, M. Karatepe, M.O. Smith, \& O. Kucuk. 2006. Effects of dietary lycopene and vitamin $\mathrm{E}$ on egg production, antioxidant status and cholesterol levels in Japanese quail. AsianAustralas J Anim Sci. 19:224-230.

Santos-Cervantes, M.E., M.E. Ibarra-Zazueta, Loarca \& G. Pina. 2007. Antioxidant and antimutagenic activities of Randia echinocarpa fruit. Plant Foods Hum Nutr. 62:71-77.

Sarica, S., E. Ciftci, E. Demir, K. Kilinc, \& Y. Yildirim. 2005. Use of an antibiotic growth promoter and two natural feed additives with and without exogenous enzymes in wheat based broiler diets. S Afr J Anim Sci. 35:6172.

Schmieder, R. \& R. Edwards. 2012. Insights into antibiotic resistance through metagenomic approaches. Future Microbiol. 7(1):73-89.

Sejati, N.I.P. 2002. Formulasi, karakterisasi kimia dan uji aktivitas anti oksidan produk minuman tradisional berbasis kunyit (Curcuma domestica Val.) dan asam jawa (Tamarindus indica Linn.). Institut Pertanian Bogor. Bogor.

Selim, N.A., S.F. Youssef, A.F. Abdel-Salam, \& S.A. Nada. 2013. Evaluations of some natural antioxidant sources in broiler diets: 1-effect on growth, physiological and immunological performance of broiler chicks. Int J Poult Sci. 12:561-571.

Seo, J., S. Lee, M.L. Elam, S.A. Johnson, J. Kang, \& B.H. Arjmandi. 2014. Study to find the best extraction solvent for use with guava leaves (Psidium guajava L.) for high antioxidantefficacy. Food Sci Nutr. 2(2):174-80.

Setiyanto, I., Sugiharto, \& H.I. Wahyuni. 2017. Pengaruh penambahan aditif kunyit terhadap profil darah putih pada ayam kampung super. Prosiding Seminar Teknologi dan Agribisnis Peternakan V: Teknologi dan Agribisnis Peternakan untuk Mendukung Ketahanan Pangan, Fakultas Peternakan Universitas Jenderal Soedirman 18 November 2017.

Shabbir, H.I. Butt, M. Shahzad, H.M Arshad, \& I. Waheed. 2016. Immunostimulatory effect of methanolic leaves extract of Psidium Guajava (guava) on humoral and cellmediated immunity in mice a. J Anim Plant Sci. 26(5):1492-1500

Sidiq, F. \& W.W. Wardani. 2014. Aktivitas antioksidan dari curcumin dalam mengurangi dampak stres oksidatif pada unggas yang terpapar cekaman panas. Trouw Add Sci. $3: 1-3$

Silva Cardoso, V., C.A. Ribeiro de Lima, M.E. Freire de Lima, L.E. Gomes Dorneles, \& M. G.M. Danelli. 2012. Piperine as a Phytogenic Additive in Broiler Chickens. Pesqui Agropec Bras. 47 (4).

Sinurat, A.P., T. Purwadaria, I.A.K. Bintang, P.P. Ketaren, N. Bermawie, M. Raharjo, \& M. Rizal. 2009. Pemanfatan kunyit dan temulawak sebagai imbuhan pakan untuk ayam broiler. JITV 14:90-96.

Sinurat, A.P., T. Purwadaria, T. Pasaribu, I.W.R. Susana, J. Dharma, J. Rosida, S. Sitompul, \& Udjianto. 2004. Efektifitas bioaktif lidah buaya sebagai imbuhan pakan untuk ayam broiler yang diperoleh di atas litter. JITV 9:145-150. 
Sinurat, A.P., T. Purwadaria, M.H. Togatorop, \& T. Pasaribu. 2003. Pemanfaatan bioaktif tanaman sebagai "feed additive" pada ternak unggas: Pengaruh pemberian gel lidah buaya atau ekstraknya dalam ransum terhadap penampilan ayam pedaging. JITV. 8:139145 .

Sinurat, A.P., E. Wina, S.I.W. Rakhmani, T. Wardhani, T. Haryati, \& T. Purwadaria. 2018. Bioactive substances of some herbals and their effectiveness as antioxidant, antibacteria and antifungi. JITV 23(1):18-27.

Sinurat, A.P. 2013. Bioaktif tanaman lidah buaya sebagai imbuhan pakan unggas. In: Sumarno TD, Soedjana, Suradisastra K, editors. Membumikan Iptek Pertanian. IAARD Press. Jakarta.

Siragusa, G.R., G.J. Haas, P.D. Matthews, R.J. Smith, R.J. Buhr, N.M. Dale, \& M.G. Wise. 2008. Antimicrobial activity of lupulone against Clostridium perfringens in the chicken intestinal tract jejunum and caecum. J Antimicrob Chemoth. 61:853-858.

Soares, G.M.S., L.C. Figueiredo, M. Faveri, S.C. Cortelli, P.M. Duarte, \& M. Feres. 2012. Mechanisms of action of systemic antibiotics used in periodontal treatment and mechanisms of bacterial resistance to these drugs. J Appl Oral Sci. 20(3):295-309.

Soares, M.C., E.T. Riberio, E.M. Kuskoski, L.V. Gonzaga, A. Lima, J.M. Filho, \& R. Fett. 2008. Composition of phenolic acids content in apple (Malus sp) pomace. J Agric Sci. 29:339-348.

Spelman, K., J.J. Burns, D. Nichols, N. Winters, S. Ottersberg, \& M. Tenborg. 2006. Modulation of cytokine expression by traditional medicines: A review of herbal immunomodulators. Alternative Med Rev. 11:128-146.

Stanacev, V., D. Glamocic, N. Milosevic, N. Puvaca, V. Stanacev, \& N. Plavsa. 2011. Effect of garlic (Allium sativum L.) in fattening chicks nutrition. Afr J Agric Res. 6:943-948.

Steiner, T. 2009. Phytogenics in Animal Nutrition : Natural Concepts to Optimize Gut Health
And Performance. Nottingham University Press. Nottingham.

Syafwan, S., R.P. Kwakkel, \& M.W.A Verstegen. 2011. Heat stress and feeding strategies in meat-type chickens. World's Poult Sci J. 67: 653-673.

Talazadeh, F., M. Mayahi, \& M. Naghavi. 2017. The Effect of Antibiofin ${ }^{\circledR}$ on the Immune Response Against Avian Influenza Subtype H9N2 Vaccine in Broiler Chickens. Int $\mathbf{J}$ Enteric Pathog. 4(3):e39396.

Tamzil, M.H. 2014. Stres panas pada unggas: metabolisme, akibat dan upaya penanggulangannya. Wartazoa 24(2):57-66.

Tan, B.K. \& J. Vanitha. 2004. Immunomodulatory and antimicrobial effects of some traditional Chinese medicinal herbs: a review. Curr Med Chem. 11:1423-30.

Tizard, I.R. 2000. Immunology: An Introduction. 6th Ed. Saunders College Publishing. New York. pp. 98-161.

Trombetta, D., F. Castelli, M.G. Sarpietro, V. Venuti, M. Cristani, C. Daniele, A. Saija, G. Mazzanti, \& G. Bisignano. 2005. Mechanisms of antibacterial action of three monoterpenes. Antimicrob Agents $\mathrm{Ch}$. 49:2474-2478.

Turan, B. 2010. Role of Antioxidants in Redox Regulation of Diabetic Cardiovascular Complications. Curr Pharm Biotech. 11:819836.

Uddin, M.J., K. Kaewmala, D. Tesfaye, E. Tholen, C. Looft, M. Hoelker, K. KarlSchellander, \& M.U. Cinar. 2013. Expression patterns of porcine Toll-like receptors family set of genes (TLR1-10) in gut-associated lymphoid tissues alter with age. Res Vet Sci. 95:92102.

Ultee, A., M.H. Bennik, \& R. Moezelaar. 2002. The phenolic hydroxyl group of carvacrol is essential for action against the food-borne pathogen Bacillus cereus. Appl Environ Microbiol. 68:1561-1568.

Vukić-Vranješ, M., N. Tolimir, D. Vukmirović, R. Čolović, V. Stanaćev, P. Ikonić, \& S. Pavkov. 2013. .Effect of phytogenic 
additives on performance, morphology and caecal microflora of broiler chickens. Biotechnol Anim Hus. 29(2):311-319.

Waldenstedt, L., J. Inborr, I. Hansson, \& K. Elwinger. 2003. Effects of astaxanthin-rich algal meal (Haematococcus Pluvalis) on growth performance, caecal campylobacter and clostridial counts and tissue astaxanthin concentration of broiler chickens. Anim Feed Sci Tech. 108:119-132.

Wallace, R.J., W. Oleszek, C. Franz, I. Hahn, K.H.C. Baser, A. Mathe, \& K. Teichmann. 2010. Dietary plant bioactives for poultry health and productivity. Bri Poult Sci. 51(4): 461-487.

Wati, T., T.K. Ghosh, B. Syed, \& S. Haldar. 2015. Comparative efficacy of a phytogenic feed additive and anantibiotic growth promoter on production performance, caecal microbial population and humoral immune response of broiler chickens inoculated with enteric pathogens. Anim Nutr. 1:213-219.

Wenk, C. 2006. Are herbs, botanicals and other related substances adequate replacements for antimicrobial growth promoters? In: Antimicrobial Growth Promoters, Barug D., Jong J. de., Kies A.K., Verste M.W.A. (eds). Wageningen Academic Publishers, The Netherlands, pp. 329-340.

Wiedosari, E. 2007. Peranan imunomodulator alami (Aloe vera) dalam sistem imunitas seluler dan humoral ening wiedosari. Wartazoa 17(4)165-171.

Windisch, W. \& A. Kroismayr. 2006. The effects of phytobiotics on performance and gut function in monogastrics. Accessed in 2006. www.feedinfo.com.

Windisch, W., K. Schedle, C. Plitzer, \& A. Kroismayr. 2008. Use of phytogenic products as feed additives for swine and poultry. J Anim Sci. 86:E140-E148.

Windisch, W., K. Schedle, Plitzner C, \& A. Kroismayr. 2008. Use of phytogenic products as feed additives for swine and poultry. Journal of Animal Science 86(14):140-148.
Windisch, W.M., K. Schedle, C. Plitzner, \& A. Kroismayr. 2008. Use of phytogenic products as feed additives for swine and poultry. J Anim Sci. 86:140-148

Yang, Y., P.A. Iji, \& M. Choct. 2009. Dietary modulation of gut microflora in broiler chickens: a review of the role of six kinds of alternatives to in-feed antibiotics. World's Poult Sci J. 65: 97-114.

Yap, P.S.X., B.C. Yiap, H.C. Ping, \& S.H.E. Lim. 2014. Essential oils, a new horizon in combating bacterial anti-biotic resistance. Open Microbiol J. 8:6-14.

Zainuddin, D., T. Wardhani, Ujianto, \& Kadiran. 2013. Suplementasi herbal dalam meningkatkan efisiensi pakan dan kesehatan ayam lokal KUB. Prosiding Nasional Pengembangan Ternak Lokal. Universitas Andalas. Padang.

Zaki, M.M., W.A. Abd El-Ghany, \& R.M.S Korany. 2016. Effect of certain phytobiotics on the immune response of newcastle disease vaccinated broiler chickens. Asian J Poult Sci. 10(3):134-140.

Zhang, G.F., Z.B. Yang, Y. Wang, W.R. Yang, S.Z. Jiang, \& G.S. Gai. 2009. Effects of ginger root (zingiber officinale) processed to different particle sizes on growth performance, antioxidant status and serum metabolites of broiler chickens. J Poult Sci. 88:2159-2166.

Zhang, S., J.H. Jung, H.S. Kim, B.Y. Kim, \& I.H. Kim. 2012. Influences of phytoncide supplementation on growth performance, nutrient digestibility, blood profiles, diarrhea scores and fecal microflora shedding in weaning pigs. Asian-Australas. J Anim Sci. 25:1309-1315.

Zhou, T.X., Z.F. Zhang, \& I.H. Kim. 2013. Effects of dietary Coptis chinensis herb extract on growth performance, nutrient digestibility, blood characteristics and meat quality in growing-finishing pigs. Asian-Australas. J Animal Science 26:108-115. 